\title{
Deriving brown carbon from multiwavelength absorption measurements: method and application to AERONET and Aethalometer observations
}

\author{
Xuan Wang ${ }^{1}$, Colette L. Heald ${ }^{1,2}$, Arthur J. Sedlacek ${ }^{3}$, Suzane S. de Sá ${ }^{4}$, Scot T. Martin ${ }^{4}$, M. Lizabeth Alexander ${ }^{5}$, \\ Thomas B. Watson ${ }^{3}$, Allison C. Aiken ${ }^{6}$, Stephen R. Springston ${ }^{3}$, and Paulo Artaxo \\ ${ }^{1}$ Department of Civil and Environmental Engineering, Massachusetts Institute of Technology, Cambridge, MA, USA \\ ${ }^{2}$ Department of Earth, Atmospheric and Planetary Sciences, Massachusetts Institute of Technology, Cambridge, MA, USA \\ ${ }^{3}$ Environmental and Climate Sciences Department, Brookhaven National Laboratory, Upton, NY, USA \\ ${ }^{4}$ School of Engineering and Applied Science, Harvard University, Cambridge, MA, USA \\ ${ }^{5}$ Pacific Northwest National Laboratory, Richard, WA, USA \\ ${ }^{6}$ Earth and Environmental Sciences Division, Los Alamos National Laboratory, Los Alamos, NM, USA \\ ${ }^{7}$ Institute of Physics, University of São Paulo, São Paulo, Brazil \\ Correspondence to: Xuan Wang (xuanw12@mit.edu)
}

Received: 17 March 2016 - Published in Atmos. Chem. Phys. Discuss.: 29 March 2016

Revised: 21 September 2016 - Accepted: 23 September 2016 - Published: 13 October 2016

\begin{abstract}
The radiative impact of organic aerosols (OA) is a large source of uncertainty in estimating the global direct radiative effect (DRE) of aerosols. This radiative impact includes not only light scattering but also light absorption from a subclass of $\mathrm{OA}$ referred to as brown carbon $(\mathrm{BrC})$. However, the absorption properties of $\mathrm{BrC}$ are poorly understood, leading to large uncertainties in modeling studies. To obtain observational constraints from measurements, a simple absorption Ångström exponent (AAE) method is often used to separate the contribution of $\mathrm{BrC}$ absorption from that of black carbon (BC). However, this attribution method is based on assumptions regarding the spectral dependence of $\mathrm{BC}$ that are often violated in the ambient atmosphere. Here we develop a new AAE method which improves upon previous approaches by using the information from the wavelengthdependent measurements themselves and by allowing for an atmospherically relevant range of $\mathrm{BC}$ properties, rather than fixing these at a single assumed value. We note that constraints on BC optical properties and mixing state would help further improve this method. We apply this method to multiwavelength absorption aerosol optical depth (AAOD) measurements at AERONET sites worldwide and surface aerosol absorption measurements at multiple ambient sites. We estimate that $\mathrm{BrC}$ globally contributes up to $40 \%$ of the seasonally averaged absorption at $440 \mathrm{~nm}$. We find that the mass
\end{abstract}

absorption coefficient of OA (OA-MAC) is positively correlated with the $\mathrm{BC} / \mathrm{OA}$ mass ratio. Based on the variability in $\mathrm{BC}$ properties and $\mathrm{BC} / \mathrm{OA}$ emission ratio, we estimate a range of $0.05-1.5 \mathrm{~m}^{2} \mathrm{~g}^{-1}$ for OA-MAC at $440 \mathrm{~nm}$. Using the combination of AERONET and OMI UV absorption observations we estimate that the $\mathrm{AAE}_{388 / 440 \mathrm{~nm}}$ for $\mathrm{BrC}$ is generally $\sim 4$ worldwide, with a smaller value in Europe $(<2)$. Our analyses of observations at two surface sites (Cape Cod, to the southeast of Boston, and the GoAmazon2014/5 T3 site, to the west of Manaus, Brazil) reveal no significant relationship between $\mathrm{BrC}$ absorptivity and photochemical aging in urban-influenced conditions. However, the absorption of $\mathrm{BrC}$ measured during the biomass burning season near Manaus is found to decrease with photochemical aging with a lifetime of $\sim 1$ day. This lifetime is comparable to previous observations within a biomass burning plume but much slower than estimated from laboratory studies. Given the large uncertainties associated with AERONET retrievals of AAOD, the most challenging aspect of our analysis is that an accurate, globally distributed, multiple-wavelength aerosol absorption measurement dataset is unavailable at present. Thus, achieving a better understanding of the properties, evolution, and impacts of global $\mathrm{BrC}$ will rely on the future deployment of accurate multiple-wavelength absorption measurements to 
which AAE methods, such as the approach developed here, can be applied.

\section{Introduction}

The radiative impacts of carbonaceous aerosols, which encompass both black carbon (BC) and organic carbon (OC), remain highly uncertain. Aerosol absorption is dominated by $\mathrm{BC}$, which is estimated to be the second largest warming agent contributing to climate change in the last Intergovernmental Panel on Climate Change (IPCC) report (IPCC, 2013). However, the uncertainty associated with the BC radiative forcing is as large as a factor of 2 (Bond et al., 2014; Myhre et al., 2013), and recent work shows that the IPCC estimate is likely biased high (Wang et al., 2014). In contrast, OC is typically treated as a purely scattering agent. However, recent studies show that some OC can also absorb light, primarily at UV wavelengths (Arola et al., 2011; Hecobian et al., 2010; Chakrabarty et al., 2010; Kirchstetter et al., 2004; Chen and Bond, 2010). This absorbing OC, socalled brown carbon $(\mathrm{BrC})$, is mainly produced from biomass burning or biofuel combustion (Washenfelder et al., 2015; Ramanathan et al., 2007) but can also be generated from secondary sources involving the photooxidation of anthropogenic and biogenic volatile organic compounds (VOCs) or aqueous-phase chemistry in cloud droplets (Graber et al., 2006; Ervens et al., 2011).

Modeling studies estimate that $\mathrm{BrC}$ contributes 20 to $40 \%$ of total carbonaceous aerosol absorption and that its absorption direct radiative effect (DRE) ranges from +0.1 to $+0.6 \mathrm{Wm}^{-2}$ (Feng et al., 2013; Lin et al., 2014; Wang et al., 2014; Saleh et al., 2015; Jo et al., 2016). However, all of these studies suffer from substantial uncertainties given that our knowledge of the sources, optical properties, and chemical transformations of $\mathrm{BrC}$ is poorly understood. Although we know that $\mathrm{BrC}$ is associated with biofuel and biomass burning combustion, the role of fuel source and burning conditions in determining $\mathrm{BrC}$ absorption is not well known. Saleh et al. (2014) and Martinsson et al. (2015) suggest that the absorption of $\mathrm{BrC}$ generated from biomass burning is correlated with the $\mathrm{BC} / \mathrm{OC}$ emission ratio. Various secondary organic aerosol (SOA) precursors are also thought to be a source of $\mathrm{BrC}$, including monoterpenes, isoprene, and nitroaromatic compounds (Laskin et al., 2015). However, the formation and abundance of these particles in the atmosphere is poorly constrained. In addition to sources, the uncertainty in estimates of $\mathrm{BrC}$ absorption is also driven by uncertainty in optical properties. For example, comparison has shown measured refractive index (RI) and absorption Ångström exponent (AAE) to differ significantly between studies (Wang et al., 2014; Laskin et al., 2015). Finally, chemical transformations may also alter the optical properties of $\mathrm{BrC}$ in the atmosphere. Some studies suggest that absorption increases during the formation and chemical aging of certain types of biogenic and aromatic SOA (Flores et al., 2014; Laskin et al., 2015), while other studies indicate that the absorption of $\mathrm{BrC}$ may decrease during photolysis (Zhong and Jiang, 2011; Lee et al., 2014; Martinsson et al., 2015). Most of these results are from laboratory experiments and require confirmation from field observations. Forrister et al. (2015) use airborne observations of two fire events to show that the absorption associated with $\mathrm{BrC}$ decreases following emission, estimating a half-life for biomass burning $\mathrm{BrC}$ absorption of $9-15 \mathrm{~h}$. However, this rate is much slower than that suggested by laboratory studies ( $5 \mathrm{~min}$ to $3 \mathrm{~h}$ ) (Zhong and Jiang, 2011; Lee et al., 2014; Zhao et al., 2015), though none of these has explored how the absorption of primary $\mathrm{BrC}$ from biomass burning evolves under oxidizing conditions. Given the above uncertainties, field measurements of $\mathrm{BrC}$ are vital not only for constraining models but also for understanding the properties and transformations of this aerosol and its radiative impacts.

To date, the only method for directly measuring $\mathrm{BrC}$ absorption involves extraction of filter samples in water, acetone, or methanol. This approach is offline and requires detailed laboratory analysis. This is therefore not a viable approach for obtaining global, continuous measurements; direct observations of $\mathrm{BrC}$ absorption from field campaigns are also limited. As a result, more indirect methods based on calculating the difference between total absorption and that of $\mathrm{BC}$ have been developed. However, it is clear that the uncertainty associated with separating $\mathrm{BrC}$ absorption from $\mathrm{BC}$ absorption is larger than the uncertainty associated with the organic extraction method, because the absorption of BC itself can be highly uncertain (Koch et al., 2009; Bond et al., 2013; Wang et al., 2014). To separate BrC absorption from total absorption from satellite or ground-based measurements, one can use complex model retrievals to determine particle type and refractive index (Tesche et al., 2011; Arola et al., 2011). The uncertainty in this approach can be very large and is hard to quantify given that it relies on multiple assumptions regarding aerosol composition and size distributions ( $\mathrm{Li}$ et al., 2009). Alternatively, because BrC primarily absorbs light in the near UV, its AAE differs from $\mathrm{BC}$, and therefore a simple AAE method can also be used to estimate $\mathrm{BrC}$ absorption:

$\mathrm{AAE}=-\frac{\ln \left(\frac{\operatorname{abs}\left(\lambda_{1}\right)}{\operatorname{abs}\left(\lambda_{2}\right)}\right)}{\ln \left(\frac{\lambda_{1}}{\lambda_{2}}\right)}$.

Here $\lambda_{1}$ and $\lambda_{2}$ are two reference wavelengths; $\operatorname{abs}(\lambda)$ is the absorption (or absorption coefficient, or AAOD) at the corresponding wavelength. We can consider the case where we have absorption measurements at three wavelengths, one in the near UV or a short wavelength including $\mathrm{BrC}$ absorption and the other two in the visible spectrum without $\mathrm{BrC}$ absorption (for example, 440,675 , and $870 \mathrm{~nm}$ ) to try to separate the 
absorption of $\mathrm{BC}$ and $\mathrm{BrC}$. If there is no dust present, the absorption at the two longer wavelengths $(675$ and $870 \mathrm{~nm})$ is solely from $\mathrm{BC}$, and the absorption at the shortest wavelength $(440 \mathrm{~nm})$ includes contributions from both $\mathrm{BC}$ and $\mathrm{BrC}$. As a result, if the $\mathrm{AAE}$ of $\mathrm{BC}$ is known, the absorption of $\mathrm{BC}$ at $440 \mathrm{~nm}$ can be calculated using the longer wavelengths measurements. Then the absorption from $\mathrm{BrC}$ can be simply derived by removing this $\mathrm{BC}$ contribution to the $440 \mathrm{~nm}$ measurements. The retrieval of continuous measurements of total aerosol absorption provided by the Aerosol Robotic Network (AERONET) of ground-based sun photometers since 1992 is an attractive resource for development of such indirect methods. Several studies have applied this idea, using empirically estimated BC-AAE to derive the BrC absorption (Russell et al., 2010; Chung et al., 2012; Bahadur et al., 2012).

In light of the critical need for observational constraints on $\mathrm{BrC}$, in this study we build on previous AAE-based efforts to estimate $\mathrm{BrC}$. We describe a new AAE method to separate $\mathrm{BrC}$ and $\mathrm{BC}$ absorption and then apply this method to derive BrC AAOD from AERONET observations as well as from a suite of Aethalometer field observations of absorption. In doing so, we aim to improve our understanding of $\mathrm{BrC}$ emissions and optical properties, as well as provide a new observational constraint for BrC modeling studies.

\section{Method for deriving $\mathrm{BrC}$ absorption from observations}

Many studies have applied the simple AAE-based approach to laboratory and field measurements. These studies typically assume $\mathrm{AAE}=1$ for $\mathrm{BC}$ to derive the $\mathrm{BrC}$ absorption (Clarke et al., 2007; Herich et al., 2011; Sandradewi et al., 2008; Yang et al., 2009; J. Liu et al., 2015; Olson et al., 2015; and references therein) However, the $\mathrm{AAE}=1$ assumption may not be representative of ambient BC. Lack and Langridge (2013) summarize a series of field measurements and find that AAE of BC (for 467 and $660 \mathrm{~nm}$ ) typically ranges from 0.8 to 1.4 . Furthermore, the assumption that $\mathrm{BC} \mathrm{AAE}=1$ under all conditions is also theoretically incorrect. Figure 1 summarizes a series of Mie calculations for single BC particles of varying size and coating. An AAE of 1 is reasonable when the diameter of the $\mathrm{BC}$ particle is smaller than $10 \mathrm{~nm}$. However, BC associated with biomass burning and biofuel sources is typically larger than $70 \mathrm{~nm}$ (Bond and Bergstrom, 2006). For these larger BC particles, the AAE is highly sensitive to the size. In addition, coating of $\mathrm{BC}$ by other materials, as is commonly observed in the atmosphere (Bond et al., 2013), also modulates the AAE. Finally, the AAE of particles $>20 \mathrm{~nm}$ is sensitive to the reference wavelengths chosen. Taken together, the assumption of $\mathrm{AAE}=1$ for ambient BC is clearly not supported by either theory or field observations, and estimates of $\mathrm{BrC}$ absorption based on this underlying assumption are subject to large errors.

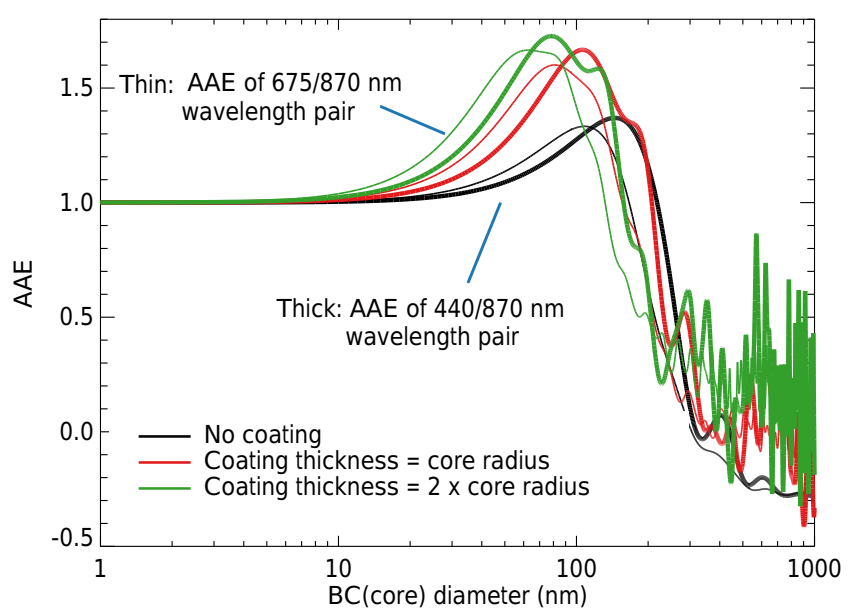

Figure 1. The Ångström absorption exponent (AAE) for BC estimated using Mie calculations as a function of size and for a series of coating states.

Several previous studies have gone beyond the AAE$\mathrm{BC}=1$ assumption and used the $\mathrm{AAE}$ to separate the $\mathrm{BC}$ (or $\mathrm{BrC}$ ) contribution from total absorption. These analyses typically rely on empirical information from previous observations. For example, Bahadur et al. (2012) and Chung et al. (2012) apply the same approach where they group AERONET sites by regions and possible source types, and by analyzing these groups, they estimate the possible AAE (or SSA or EAE) and the corresponding range for pure $\mathrm{BC}$ or pure BrC. They then apply these empirical constraints to estimate the $\mathrm{BC}$ or $\mathrm{BrC}$ contributions at other sites. $\mathrm{Ba}$ hadur et al. (2012) used this method and found that $\mathrm{BrC}$ contributes $28 \%$ of the total aerosol absorption at $440 \mathrm{~nm}$ in North America. Chung et al. (2012) concluded that $~ 20 \%$ of the absorption DRE estimated in previous global studies for $\mathrm{BC}$ should be attributed to BrC. This approach assumes that the AAE is an intrinsic property by composition; however, it is clear from Fig. 1 that the AAE is strongly sizedependent, and may therefore vary geographically with combustion conditions. These methods can also only be applied within a given dataset, such as AERONET.

Here we develop a novel method to derive BrC absorption using multiple-wavelength absorption measurements. This AAE-based method does not rely on assumed or empirically estimated $\mathrm{BC}$ and $\mathrm{BrC}$ AAE values as in previous studies; rather, it combines multiple-wavelength absorption measurements with theoretical Mie calculations for BC. As shown in Fig. 1, the AAE of BC is different when using different reference wavelength pairs. We characterize the WDA (wavelength dependence of absorption Ångström exponent) to describe this difference. This WDA can be seen as the wavelength dependence of the wavelength dependence of absorption, which provides additional information on the aerosol properties that has not been exploited in previous studies. As- 
suming that we have absorption measurements at 440,675 , and $870 \mathrm{~nm}$, then

$\mathrm{WDA}=\mathrm{AAE}_{440 / 870}-\mathrm{AAE}_{675 / 870}$,

and in the absence of $\mathrm{BrC}$, the $\mathrm{AAE}_{440 / 870}$ and $\mathrm{AAE}_{675 / 870}$ are the AAE of BC calculated using the $440 \mathrm{~nm} / 870 \mathrm{~nm}$ and $675 \mathrm{~nm} / 870 \mathrm{~nm}$ wavelength pairs. Note that the assumption of wavelength-independent $\mathrm{AAE}=1$ for $\mathrm{BC}$ would lead to a WDA of 0 . For a given population of $\mathrm{BC}$ particles, we can use Mie theory to calculate a WDA value by assuming that the particles are spherical. The observed size distribution of $\mathrm{BC}$ is typically lognormal, with geometric median diameter (GMD) ranging from 20 to $300 \mathrm{~nm}$ and standard deviation $(\delta)$ ranging from 1.4 to 2.2 (Akagi et al., 2012; Schwarz et al., 2008; Lack et al., 2012; Dubovik et al., 2002; Shamjad et al., 2012; Moffet and Prather, 2009; Knox et al., 2009; Lewis et al., 2009). We perform Mie calculations using these size distributions and a refractive index of 1.95-0.79i, as suggested by Bond and Bergstrom (2006). We also perform an additional set of calculations for coated BC. The refractive index for coated material is assumed to be $1.55-0.001 i$, which is the typical value for non-absorbing organic and inorganic (Kopke et al., 1997). We first assume the coating thickness is $10-100 \%$ of the BC core radius and then only select the calculations with absorption enhancement smaller than a factor of 2. This is supported by field measurements and most laboratory experiments (Schwarz et al., 2008; Lack et al., 2012; Moffet and Prather, 2009; Cappa et al., 2012; Bueno et al., 2011; Shiraiwa et al., 2010; Shamjad et al., 2012; Knox et al., 2009; S. Liu et al., 2015). Figure 2 shows the range (shaded region) of calculated WDA of $\mathrm{BC}$ versus $\mathrm{AAE}_{675 / 870}$ that we estimate based on the above assumptions.

The black line is the median value of the WDA of $\mathrm{BC}$ as a

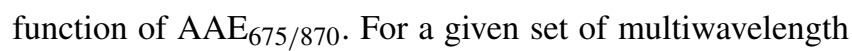
absorption measurements, if the calculated WDA falls above the shaded region, this suggests that there are components other than BC in the sample which absorb light more strongly at $440 \mathrm{~nm}$ than at longer wavelengths, supporting the presence of $\mathrm{BrC}$. To illustrate this we take the AAOD measured at all the sites of the global AERONET network as an example. AERONET is a global ground-based aerosol observation network of radiometers (Dubovik and King, 2000; Holben et al., 2001). AERONET AAOD can be calculated at four wavelengths $(440,675,870$, and $1020 \mathrm{~nm})$ based on aerosol optical depth (AOD) and single-scattering albedo (SSA), which are retrieved by measuring the sky radiance in a wide angular range. The latest version 2 AERONET product includes two levels of data: 1.5 (cloud-screened) and 2 (cloud-screened and finally quality-assured). The level-2 AERONET SSA data are only available under high AOD conditions (AOD $>0.4$ at $440 \mathrm{~nm}$ ) (Dubovik and King, 2000; Dubovik et al., 2002 ); this subset is only $20 \%$ of the level- 1.5 measurements, which makes the level-2 AAOD biased towards highaerosol loading conditions. As we want to estimate $\mathrm{BrC}$ absorption for a wider range of conditions in the atmosphere,

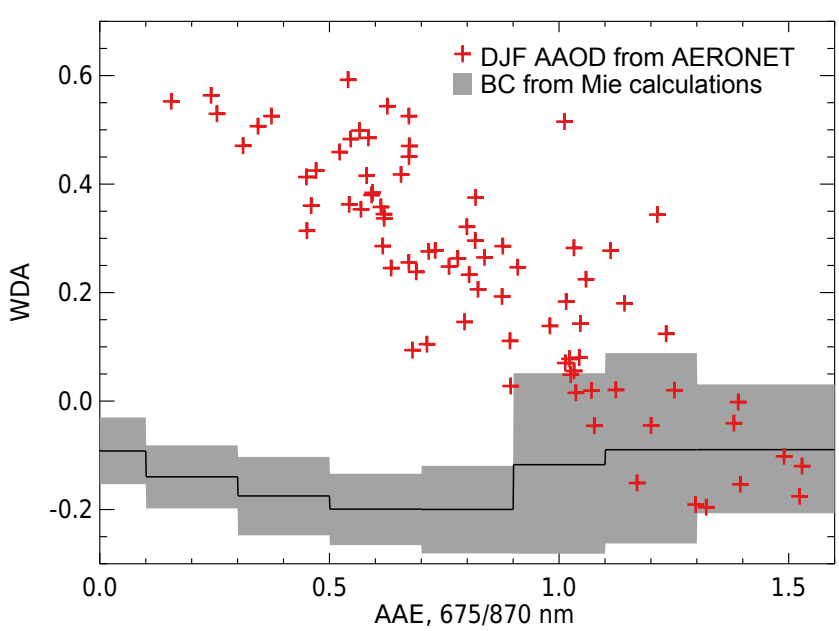

Figure 2. The range in the estimated wavelength dependence of AAE (WDA) for BC (shaded region) based on Mie calculations (see Sect. 2 for size and coating assumptions). The black line is the median WDA. Red crosses show the total absorption from 20052014 10-year seasonal average AAOD measurements at three wavelengths from the AERONET network in north hemisphere winter (December, January, and February). Observations which lie above the shaded region include detectable contributions of $\mathrm{BrC}$ absorption.

we use the level-2 AOD and SSA in addition to recovering the missing SSA from level-1.5 in the following analysis. The uncertainty in partially using level-1.5 SSA is hard to estimate, but it could be small for our BrC contribution analysis if such uncertainties are similar at all wavelengths.

While AERONET provides global observations of the column-integrated AOD, few of these sites actually have continuous measurements of AAOD throughout the year because the SSA is not always retrieved. For example, more than half of the AERONET sites measured AAOD for only 1 month in 2014. As a result, we use the data from the past decade (2005-2014) to enhance our sampling. To reduce the influence of sporadic events in the analysis, when showing the 10 -year seasonal average value, only sites with data for more than 6 years within a given season are selected. The AAOD from AERONET reflects not only the absorption from BC and $\mathrm{BrC}$ but also that from dust. We use two thresholds to exclude the data possibly affected by dust. First, we use the coarse-mode AOD contribution (at $440 \mathrm{~nm}$ ) provided by AERONET. We assume that dust controls the total extinction of particles larger than $1 \mu \mathrm{m}$ diameter (coarse-mode), and therefore remove data with a coarse-mode AOD contribution $>10 \%$ from our analysis. Second, we apply the strict filtering of AERONET observations proposed by Russell et al. (2010) and Chung et al. (2012), excluding data with extinction Ångström exponent (EAE) <1, as well as Bahadur et al. (2012), excluding data exhibiting scattering Ångström exponent $(\mathrm{SAE})<1.2$ and $\mathrm{AAE}_{675 / 870} / \mathrm{AAE}_{440 / 675}<0.8$. Bahadur et al. (2012) refer to data filtered by this criterion as 
"dust-free". However, we note that AERONET observations are not a direct measurement of absorption but instead a retrieved quantity, and though we have attempted to minimize dust contamination in this dataset, retrieval assumptions may also impact our analysis. This is discussed in further detail in Sect. 3, but here we apply our methodology to AERONET observations primarily for illustration purposes.

The red crosses in Fig. 2 show the calculated WDA using the seasonal average observed AAOD from the global AERONET network in northern hemispheric winter (December, January, and February, same sites in Fig. 3a). Many points fall within the shaded region, suggesting that the absorption for these sites at $440 \mathrm{~nm}$ is primarily from BC. We cannot preclude the presence of $\mathrm{BrC}$ in these samples, but the contribution is likely small and cannot be estimated using our method without additional information about the size and coating state of BC particles. BrC is clearly present (and contributing to the absorption at $440 \mathrm{~nm}$ ) for the remaining sites which lie above the shaded region. We calculate the highest and lowest possible BrC absorption at $440 \mathrm{~nm}$ based on the lowest and highest WDA (WDA 1 and $\mathrm{WDA}_{2}$ ) as follows:

$$
\begin{aligned}
& \mathrm{BCAAE}_{440 / 870}=\mathrm{AAE}_{675 / 870}+\mathrm{WDA}, \\
& \mathrm{BrCabs}(440)=\operatorname{abs}(440)-\mathrm{BC} \text { abs }(440) .
\end{aligned}
$$

The $\mathrm{BrC}$ absorption at $440 \mathrm{~nm}$ is calculated as the median of these highest and lowest possible absorptions. For those points that fall within the shaded region, the $\mathrm{BrC}$ absorption is determined as the median of the highest possible absorption and 0 . The methodological uncertainty varies as a function of the relative amount of $\mathrm{BrC}$ and the measured wavelengths. For example, with measurements of absorption at 440,675 , and $870 \mathrm{~nm}$ wavelengths, BrC must contribute at least $4 \%$ of the total absorption at $440 \mathrm{~nm}$ to be detected by this approach. This implies a "detection limit" to this approach, where contributions of $4 \%$ or less of $\mathrm{BrC}$ to total absorption cannot be identified. This detection limit varies with $\mathrm{AAE}$, and is highest when the $\mathrm{AAE}$ of $\mathrm{BC}$ is in the range of 1.1 to 1.3 . We also estimate the methodological uncertainty range for $\mathrm{BrC}$ absorption at $440 \mathrm{~nm}$ by repeating this calculation using the lowest and highest WDA value of the shaded region $\left(\mathrm{WDA}_{1}\right.$ and $\left.\mathrm{WDA}_{2}\right)$. For conditions with $\mathrm{AAE}_{675 / 870}$ $>1$, the methodological uncertainty of derived $\mathrm{BrC}$ absorption at $440 \mathrm{~nm}$ using the above wavelengths is smaller than $28 \%$ when the $\mathrm{BrC}$ absorption contribution is larger than $30 \%$, but could be as large as $110 \%$ when the $\mathrm{BrC}$ contributes around $10 \%$ of the total absorption. For conditions

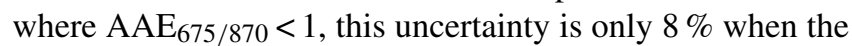
real $\mathrm{BrC}$ absorption contribution is larger than 30 and $35 \%$ when the contribution is $10 \%$. Given the modest range in the calculated WDA for $\mathrm{BC}(<25 \%)$, this method decreases the uncertainty in estimated $\mathrm{BrC}$ compared to the traditional $\mathrm{BC}$ $\mathrm{AAE}=1$ method. Lack and Langridge (2013) show that the bias in the traditional $\mathrm{BC} \mathrm{AAE}=1$ method is also associated with the $\mathrm{BrC} / \mathrm{BC}$ ratio. The bias from that method is smaller than $33 \%$ when BrC contributes $23-41 \%$ of total absorption but much larger (more than $100 \%$ ) for other BrC contributions. In contrast, for the annual mean observations from the global AERONET network in 2014 that lie above the shaded $\mathrm{BC}$ region shown in Fig. 2, the uncertainty of $\mathrm{BrC}$ absorption derived using our method is smaller than $25 \%$. The spherical assumption in the Mie calculations could lead to additional uncertainties, as previous work suggests that the shape of BC can affect both the SSA and the absorption enhancement from coating (Adachi et al., 2010; Kahnert and Devasthale, 2011). However, this uncertainty is hard to estimate since it is difficult to quantify how particle shape influences AAE and WDA. Our estimated BrC absorption is the externally mixed $\mathrm{BrC}$ absorption, which does not include the influence of $\mathrm{BrC}$ coated on BC. This is consistent with $\mathrm{BrC}$ measurements as the absorption of coated $\mathrm{BrC}$ is included in the absorption of $\mathrm{BC}$ and cannot be measured separately.

In contrast to previous AAE-based methods, our approach uses the theoretical relationship between AAE and WDA for BC shown in Fig. 2 in combination with the observed total AAE, and does not rely on any other data. This also makes our method "wavelength-flexible". Although we use $440 / 675 / 870 \mathrm{~nm}$ to describe our method, any three wavelengths with one in the near UV and two at longer wavelengths in the visible spectrum can be used.

As the absorption from primary OA (Br-POA) from biofuel and biomass burning typically dominates that of absorbing SOA (Br-SOA) (Martinsson et al., 2015; Laskin et al., 2015), the absorption of Br-SOA is much more challenging to detect than Br-POA in most field measurements. We therefore focus our analysis on the primary sources of $\mathrm{BrC}$.

\section{AERONET network and data analysis}

\subsection{Global BrC-AAOD from AERONET}

Figure 3 shows the derived AERONET BrC-AAOD at $440 \mathrm{~nm}$ in different seasons. Our BrC-AAOD calculation is based on the daily data from AERONET. This is different from the data points in Fig. 2 (10-year seasonally averaged data, only for illustration). The AERONET observations of wavelength-dependent absorption are retrieved from the direct and diffuse radiation measured by sun/sky radiometers, but they do not include any aerosol assumptions such as those used in the AERONET retrieval of refractive index and size distribution. AERONET AAOD is widely used to investigate the sources, compositions, and properties of aerosols (Russell et al., 2010; Bond et al., 2014; Sayer et al., 2014). However, we show that the retrieval is an indirect measure of aerosol absorption and that uncertainties and assumptions in the retrieval scheme may impact the reported multiwavelength absorption and introduce subtle inconsistencies with our assumed population of particles. Given the paucity of direct measurements of multiwavelength absorption (see datasets described in Sect. 4), we apply our methodology to 

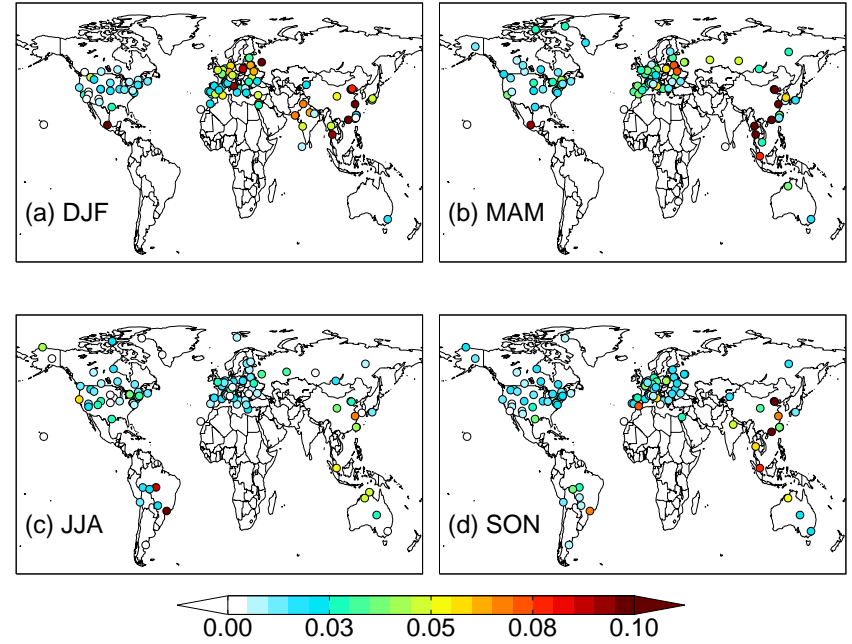

Figure 3. Derived seasonal mean $\mathrm{BrC}-\mathrm{AAOD}$ at $440 \mathrm{~nm}$ from AERONET observations (2005-2014, 10-year average) in northern hemispheric (a) winter, (b) spring, (c) summer, and (d) fall. The color bar is saturated at 0.010 to emphasize regional variations, but maximum values reach 0.056 .

the AERONET observations to provide a first-look constraint on global BrC AAOD.

The accuracy of specific numerical values presented below is challenging to estimate, and we provide these values for completeness in the text; however, we focus our conclusions on the qualitative spatial and seasonal differences in estimated $\mathrm{BrC}$, which are likely more robust.

For the data points below the methodology detection limit, we calculate the BrC-AAOD as the mean of 0 and the associated detection limit; the mean BrC-AAOD for these points is $0.0034 \pm 0.05$. The fraction of the data below the detection limit is $22 \%$ globally and is regionally consistent. In general, the seasonal average BrC-AAOD is smaller than 0.005 at most sites but larger in Asia. The BrC-AAOD can be as large as 0.056 in the winter at the site near Beijing. The average BrC-AAOD derived at AERONET sites is 0.0031 globally, 0.0018 in North America, 0.0026 in Europe, 0.0119 in East Asia, and 0.004 in South America. The mean BrC-AAOD in the major biomass burning season in Southeast Asia (spring, 0.006 ) is $\sim 60 \%$ higher than non-biomass-burning seasons (0.038). In contrast, no significant seasonal variations are found in other regions (data in South America are only available during biomass burning seasons due to the data filtering). The sites in Africa exhibit low BrC-AAOD even during biomass burning seasons. This is because nearly all the data with high AAOD in Africa are excluded from the analysis due to the influence of dust.

Figure 4 shows the contribution of BrC-AAOD to total AAOD at $440 \mathrm{~nm}$ at each AERONET site. The annual mean BrC AAOD contribution falls below $30 \%$ at $80 \%$ of the AERONET sites. Generally, East Asia and Europe in northern hemispheric winter have higher BrC AAOD con-
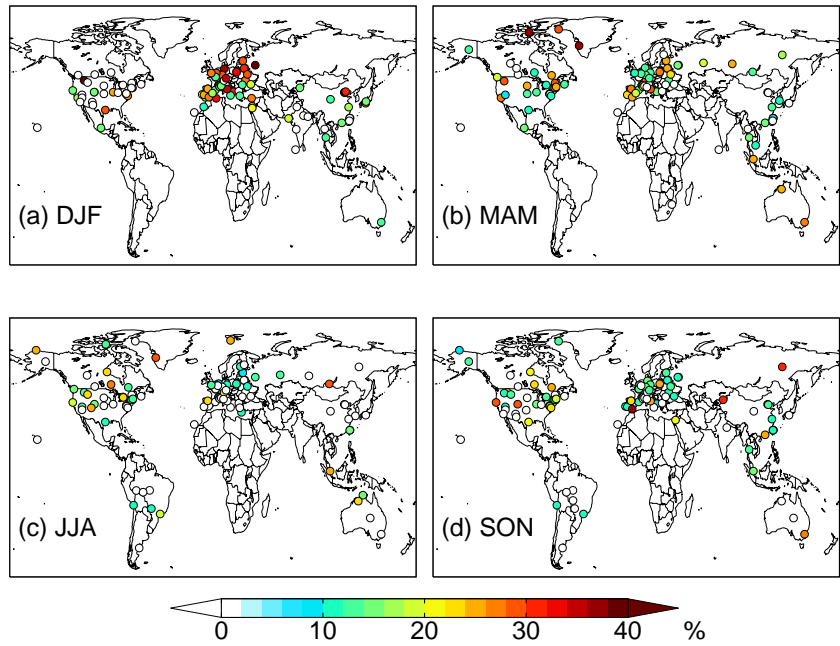

Figure 4. Derived seasonal mean BrC-AAOD contributions to total AAOD at $440 \mathrm{~nm}$ from AERONET observations (2005-2014, 10-year average) in northern hemispheric (a) winter, (b) spring, (c) summer, and (d) fall. The color bar is saturated at $40 \%$ to capture regional variation, but values up to $45 \%$ are estimated at specific sites.

tributions (28 and $21 \%$ ) than other regions/seasons (average $10 \%)$. Our estimate in the California region (14\% in the north and $11 \%$ in the south) is comparable with that of Bahadur et al. (2012) (15\% in the north and $9 \%$ in the south) during winter and spring, but smaller during summer and fall $(\sim 12 \%$ vs. $\sim 30 \%)$. The OC in both East Asia and Europe has large contributions from residential heating using biofuel, which suggests such biofuel emissions of OC may be more absorbing than other sources that dominate in other seasons. In contrast, in Southeast Asia, the contributions of $\mathrm{BrC}$ to total AAOD are relatively aseasonal $(<5 \%$ seasonal differences). As the absolute value of BrC-AAOD is larger in the fire season but the contribution of $\mathrm{BrC}$ to total absorption is not, the $\mathrm{BrC}$ absorption associated with biomass burning from large scale fires may not be very different from the other sources that dominate in other seasons.

The uncertainty in our derived BrC-AAOD (described in Sect. 2) is different at each site. More than $90 \%$ of all the daily data in these 10 years have a methodological uncertainty smaller than $30 \%$. The methodological uncertainty at a given site at a given hour can be as high as $100 \%$. However, very low BrC-AAOD values are derived for these highly uncertain data, having little impact on the 10-year-averaged BrC-AAOD. Since AAE $<1$ is frequently $(60 \%$ of the observations for the wavelength pair of $675 / 870 \mathrm{~nm}$ ) observed at most AERONET sites, substantial $\mathrm{BrC}$ absorption would be misattributed to $\mathrm{BC}$ using the simple $\mathrm{BC}-\mathrm{AAE}=1$ method. By assuming $\mathrm{BC}-\mathrm{AAE}=1$, the global mean $\mathrm{BrC}-\mathrm{AAOD}$ at $440 \mathrm{~nm}$ would be estimated as only $0.001,40 \%$ lower than our estimate. 
One challenge of this analysis is the well-known uncertainties associated with the AERONET observations. The measurement uncertainty is \pm 0.01 for AOD and \pm 0.03 for SSA when AOD $>0.2$, and it could be as large as \pm 0.07 for SSA when AOD $<0.2$. The uncertainty of AAOD depends on the corresponding AOD value; for example, this uncertainty is \pm 0.015 with $\mathrm{AOD}=0.4$ (Dubovik et al., 2002). Because our method is sensitive to the AAE not the AAOD, the uncertainty could be small for our BrC contribution analysis if such uncertainties from AERONET are similar at all wavelengths. If the AERONET AAOD uncertainties vary substantially with wavelength, the influence on our analysis could be large and hard to quantify. In addition, the AERONET uncertainties suggest AAOD $<0.01$ is certainly below the observed detection limit. In Fig. 3 and in the above discussion, most sites exhibit derived BrC-AAOD smaller than 0.01. However, all of these values are seasonal means over 10 years and include both non-BrC detected (BrC-AAOD 0) data and $\mathrm{BrC}$ detected data. If instead we replace the $\mathrm{BrC}-\mathrm{AAOD}<0.01$ data points by $\mathrm{BrC}-\mathrm{AAOD}=0.005$ (the median of 0 and 0.01 ), the results are very similar.

In our method, we assume that the $\mathrm{BrC}$ absorption contribution is negligible at 675 and $870 \mathrm{~nm}$. This is supported by the laboratory measurements (Chen and Bond, 2010; Zhang et al., 2013; Yang et al., 2009; Kirchstetter et al., 2004). However, Alexander et al. (2008) find the $\mathrm{BrC}$ absorption may be significant at $675 \mathrm{~nm}$ by examining an electron energy-loss spectrum from a transmission electron microscope. If $\mathrm{BrC}$ absorbs significantly at $675 \mathrm{~nm}$, our estimate of BrC absorption at $440 \mathrm{~nm}$ would be underestimated.

\subsection{Relationship between BrC-AAOD and BC-AAOD}

Figure 5 compares the derived BrC-AAOD at $440 \mathrm{~nm}$ and BC-AAOD at $675 \mathrm{~nm}$ at AERONET sites for 2005-2014. As $\mathrm{BrC}$ absorbs little light at wavelengths longer than $600 \mathrm{~nm}, \mathrm{BC}-\mathrm{AAOD}$ is effectively equivalent to total AAOD at $675 \mathrm{~nm}$. Globally, the BrC-AAOD and BC-AAOD are moderately well correlated ( $R^{2} \sim 0.6$, not shown in Fig. 5). To identify whether the correlation is different under different conditions, we further disaggregate the data by emission type and region. We use the anthropogenic emission inventory of Bond et al. (2007) and biomass burning emission inventory from GFED4 (Giglio et al., 2013) to identify the dominant emission type for each data point. For a given month, if the biofuel or biomass burning emissions of both $\mathrm{BC}$ and $\mathrm{OC}$ contribute more than $60 \%$ of the total emissions in a $2^{\circ} \times 2^{\circ}$ area around a given AERONET site, we identify the corresponding data points as dominated by that source ( $70 \%$ of data points that do not meet this criterion and are thus excluded). The results are summarized in Figure 5. After the data are separated by dominant source, the correlation between BrC-AAOD and BC-AAOD increases in all regions except the biomass-burning-dominated European sites. The correlation slope of $\mathrm{BrC}-\mathrm{AAOD} / \mathrm{BC}-\mathrm{AAOD}$ varies by region but is similar for different sources in the same region. Although we select the data using emissions in the surrounding $2^{\circ} \times 2^{\circ}$ area to denote the regional influence, this separation may be inaccurate if long-range transport is a significant source of carbonaceous aerosol at a given site. In addition, this data separation is not able to account for the variability in combustion fuel and conditions. In East Asia, the correlation slope $(m)$ between BrC-AAOD and BC-AAOD is $\sim 0.9$. It decreases to $\sim 0.5$ in other regions.

$\mathrm{BrC}_{\mathrm{AAOD}}=m \times \mathrm{BC}_{\mathrm{AAOD}}$

Equation (5) provides a simple method to estimate the absorption of $\mathrm{BrC}$ by measuring $\mathrm{BC}$ absorption. On average, globally, BrC-AAOD at $440 \mathrm{~nm}$ is roughly $50 \%(m \sim 0.5)$ of the BC-AAOD at $675 \mathrm{~nm}$ based on global AERONET data.

The AAOD is the total column absorption of aerosols, which can be written as the product of column aerosol mass and the mass absorption coefficient (MAC) of aerosols. Based on the linear relationship between BrC-AAOD and $\mathrm{BC}-\mathrm{AAOD}$, we are able to connect the MAC of OC (identical to the MAC of $\mathrm{BrC}$ when assuming all $\mathrm{OC}$ are $\mathrm{BrC}$ ) with the mass ratio of $\mathrm{BC} / \mathrm{OC}$ :

$\mathrm{MAC}_{\mathrm{OC}}=m \times \mathrm{MAC}_{\mathrm{BC}} \times \frac{\operatorname{Mass}_{\mathrm{BC}}}{\operatorname{Mass}_{\mathrm{OC}}}$.

The MAC of OC is related to the properties of OC such as size distribution, mixing state, hygroscopic growth, and refractive index (RI). Generally, there is a positive correlation between the MAC and the imaginary part of the RI $(i)$ although the relationship is not linear (Bond and Bergstrom, 2006). This tells us that the $i$ of $\mathrm{BrC}$ is likely to be positively correlated with the mass ratio of $\mathrm{BC} / \mathrm{OC}$ in a certain environment, as shown by Saleh et al. (2014). The observed relationships shown in Fig. 5 confirm that the absorption properties of $\mathrm{BrC}$ are likely related to the emission ratio of $\mathrm{BC} / \mathrm{OC}$, which further connects to fuel types and combustion conditions. The absorptivity of OC emitted from sources with higher $\mathrm{BC} / \mathrm{OC}$ is likely to be higher.

Both the $\mathrm{BC}$ optical properties and the $\mathrm{BC} / \mathrm{OC}$ ratio may vary under different conditions. It is therefore challenging to estimate the MAC of OC accurately based on Eq. (6). However, we can estimate typical values of regional average MAC of OC given that the regional BC / OC emission ratios do not vary substantially in emission inventories, and assuming that the emission ratio of $\mathrm{BC} / \mathrm{OC}$ is a reasonable proxy for the mass concentration ratio (i.e. relative differences in losses and sources are negligible). Based on the biofuel emissions of Bond et al. (2007), the BC / OC emission ratio is $0.18 \pm 0.03$ in North America and Europe and $0.24 \pm 0.06$ in other regions. The $\mathrm{BC} / \mathrm{OC}$ emission ratio for biomass burning in the GFED4 inventory is $0.12 \pm 0.06$ for different source types. Considering the typical size distributions and coating thickness for $\mathrm{BC}$ from biofuel and biomass burning sources, the MAC of BC from these sources is calculated to 

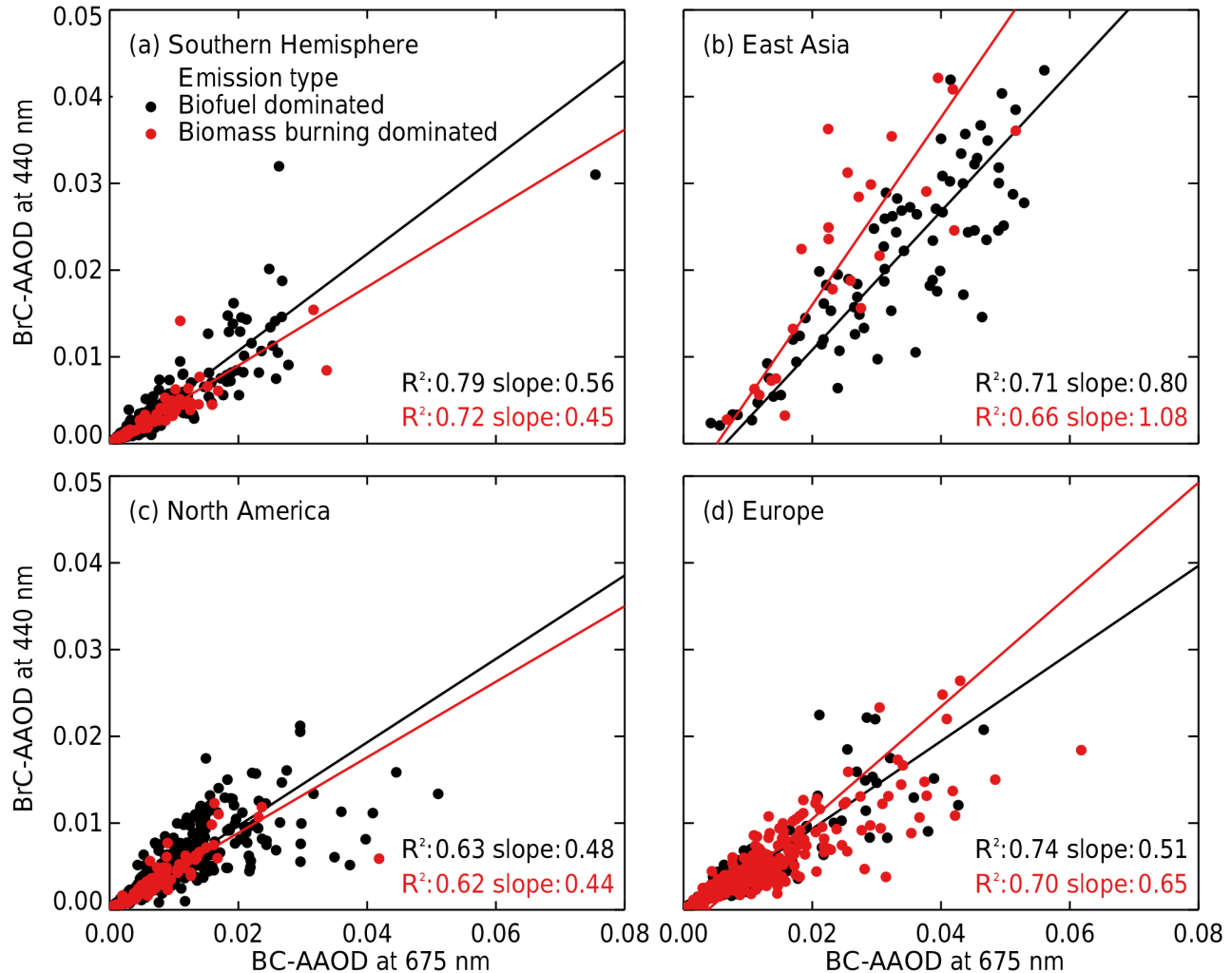

Figure 5. The relationship between monthly mean derived AERONET BrC-AAOD at $440 \mathrm{~nm}$ and BC-AAOD at $675 \mathrm{~nm}$ at AERONET stations in (a) North America, (b) East Asia, (c) Europe, and (d) Southern Hemisphere for the years 2005-2014.

be $7.8 \pm 5 \mathrm{~m}^{2} \mathrm{~g}^{-1}$ by Mie theory (Wang et al., 2014). We therefore estimate the average MAC of OC to be $0.7 \mathrm{~m}^{2} \mathrm{~g}^{-1}$ from biofuel in North America/Europe, $0.94 \mathrm{~m}^{2} \mathrm{~g}^{-1}$ from biofuel in other regions, and $0.47 \mathrm{~m}^{2} \mathrm{~g}^{-1}$ from biomass burning at $440 \mathrm{~nm}$. Taking the mass ratio of total organic aerosol (OA) and OC to be 2.1 (Turpin and Lim, 2001; Aiken et al., 2008), the corresponding MAC for OA are $0.33,0.45$, and $0.22 \mathrm{~m}^{2} \mathrm{~g}^{-1}$. Considering the variability in the correlation slopes in Fig. 5, the BC / OC emission ratios, the size distribution, and the mixing state of $\mathrm{BC}$, we estimate a range of MAC of $0.1-3.1 \mathrm{~m}^{2} \mathrm{~g}^{-1}$ for OC and $0.05-1.5 \mathrm{~m}^{2} \mathrm{~g}^{-1}$ for OA at $440 \mathrm{~nm}$. The upper limit is comparable to the highest MAC of acetone/methanol-soluble OA found in laboratory experiments (Kirchstetter et al., 2014; Yang et al., 2009). We note that these estimates of OC-MAC (or OA-MAC) are subject to uncertainties associated with the AERONET retrieval of absorption. It should be mentioned that the MAC of OA reflects both the BrC-MAC and the BrC contribution to the total OA. Since we cannot isolate the $\mathrm{BrC}$ contribution to $\mathrm{OA}$, we use the term OA-MAC instead of BrC-MAC to characterize the absorption of $\mathrm{OA}$ in this and following analysis.

\subsection{BrC-AAE from combining AERONET and OMAERUV data}

From AERONET data, we can derive BrC-AAOD at one wavelength only $(440 \mathrm{~nm})$. However, this is insufficient for estimating the full radiative impacts of $\mathrm{BrC}$. To estimate the $\mathrm{AAE}$ of $\mathrm{BrC}, \mathrm{AAOD}$ with at least one more near-UV wavelength is needed. Here we use the OMAERUV (Ozone Monitoring Instrument near-UV aerosol algorithm) (Torres et al., 2007; Ahn et al., 2014) product together with AERONET to calculate the $\mathrm{AAE}$ of $\mathrm{BrC}$.

OMI is a nadir-viewing spectrometer aboard NASA's Earth Observing System's (EOS) Aura satellite. The Aura polar-orbiting satellite orbits with a 16-day repeat cycle and a local Equator-crossing time of 13:45 $\pm 15 \mathrm{~min}$. OMI measures near-UV radiance at 354 and $388 \mathrm{~nm}$ and reports AOD, $\mathrm{SSA}$, and AAOD at 354,388 , and $500 \mathrm{~nm}$ with a spatial resolution of $13 \mathrm{~km} \times 24 \mathrm{~km}$. The AAOD at $388 \mathrm{~nm}$ is directly retrieved from radiance absorption, while the other two wavelengths are derived from $388 \mathrm{~nm}$ data. In the analyses below, we use the AAOD at $388 \mathrm{~nm}$ from the level-3 OMAERUVd gridded product and only select the highestquality data by filtering out retrievals affected by large solar zenith angle $\left(>70^{\circ}\right)$, out-of-bounds AOD $(>6$ at $500 \mathrm{~nm})$ or SSA $(>1)$, low terrain pressure $(<628.7 \mathrm{hPa})$, cloud contam- 

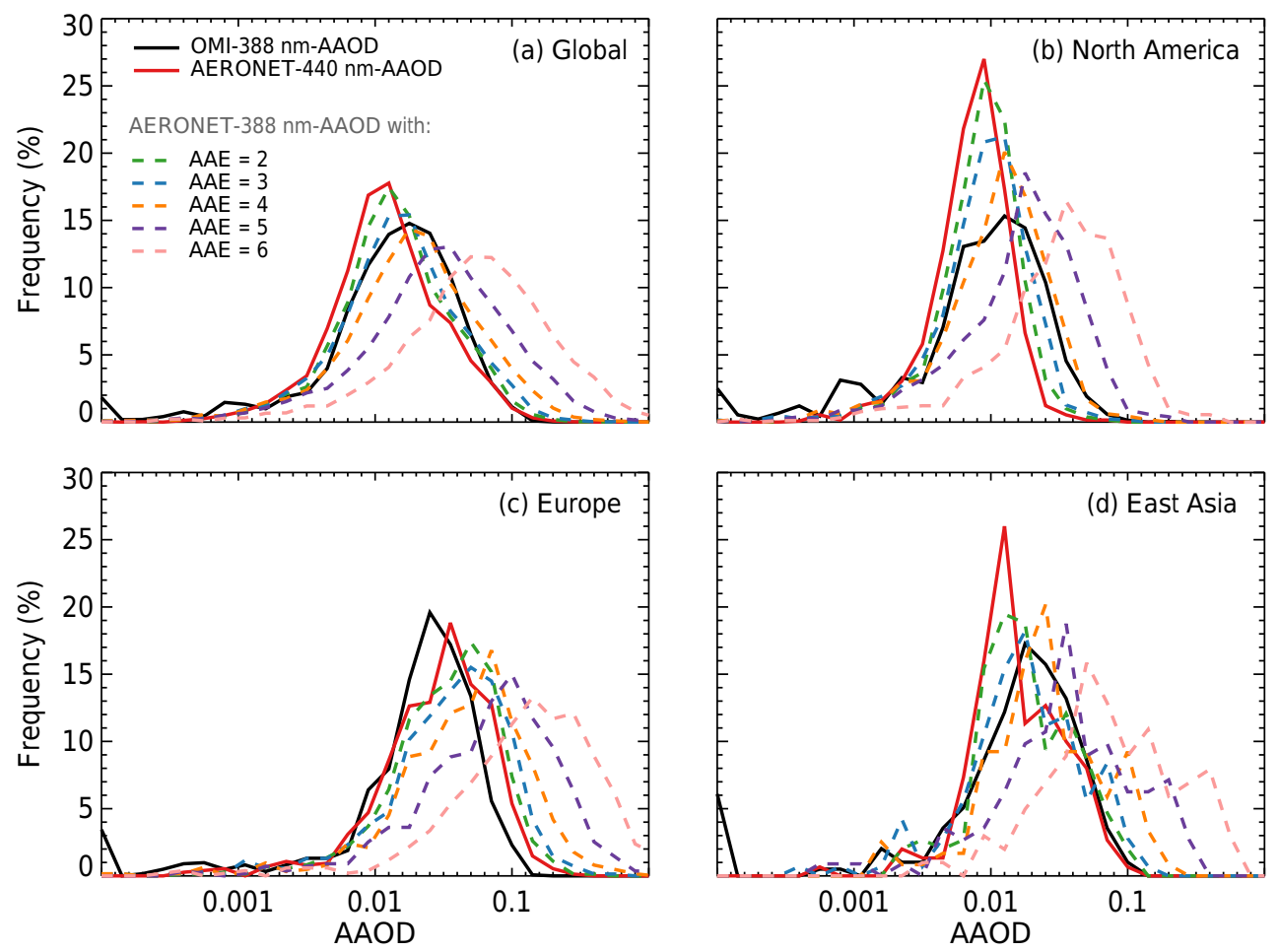

Figure 6. Frequency distributions of the AAOD measured by OMI at $388 \mathrm{~nm}$ (black) and AERONET at $440 \mathrm{~nm}$ (red), as well as AERONET observations adjusted to $388 \mathrm{~nm}$ using a range of assumed AAE for $\mathrm{BrC}$ (dashed lines) for (a) the whole world, (b) North America, (c) Europe, and (d) East Asia. Details can be found in Sect. 3.4.

ination, and cross-track anomaly. The root mean square error of the AAOD is estimated to be $\sim 0.01$ (Torres et al., 2007).

Given that the measurement methods of AERONET and OMAERUV are very different and the temporal coverage of both are relatively poor, we do not combine the OMAERUV AAOD at $388 \mathrm{~nm}$ with the AERONET AAOD at other wavelengths to calculate BrC-AAOD at $388 \mathrm{~nm}$ for each AERONET site. Instead, we statistically compare AAOD observations in different regions between these two products. We assume that the distribution of AAOD from a large group of data points should be similar between AERONET and OMAERUV despite differences in the measurement approach. In Fig. 6, the frequency distributions for AAOD of OMAERUV ( $388 \mathrm{~nm}$ ) and AERONET $(440 \mathrm{~nm})$ are plotted as solid black and red lines. To compare the observations at the same wavelength, we transfer the AERONET AAOD to $388 \mathrm{~nm}$ by fixing the $\mathrm{AAE}_{388 / 440 \mathrm{~nm}}$ of $\mathrm{BC}$ and $\mathrm{BrC}$. When assuming $\mathrm{AAE}_{388 / 440 \mathrm{~nm}}=1$ for $\mathrm{BC}$, the $388 \mathrm{~nm}$ AERONET AAOD distribution with different BrC-AAE $388 / 440 \mathrm{~nm}$ is shown as dashed lines in Fig. 6. Assuming that a different $\mathrm{BC}-\mathrm{AAE}_{388 / 440 \mathrm{~nm}}$ in the range of 0.5 to 1.5 only slightly alters the dashed lines with $\mathrm{BrC}$ $\mathrm{AAE}_{388 / 440 \mathrm{~nm}}=2$, other dashed lines are largely unaffected. This arises due to the dominance of $\mathrm{BrC}$ on total AAE when BrC-AAE $388 / 440 \mathrm{~nm}>2$.
In Fig. 6a, it is clear that the $388 \mathrm{~nm}$ AERONET AAOD distribution with $\mathrm{BrC}-\mathrm{AAE}_{388} / 440 \mathrm{~nm}=4$ (orange dashed line) is the best match to the OMAERUV AAOD (black solid line). This suggests the global mean AAE of $\mathrm{BrC}$ should be $\sim 4$. Similar results are found in North America (Fig. 6b), East Asia (Fig. 6c), and the rest of the world except Europe. In Europe, regardless of our choice of $\mathrm{BrC}$ $\mathrm{AAE}_{388 / 440 \mathrm{~nm}}$, the $388 \mathrm{~nm}$ AERONET AAOD distribution does not match the OMAERUV AAOD. This suggests that both $\mathrm{BC}$ and $\mathrm{BrC}$ may have smaller AAE in Europe. As previously mentioned, when $\mathrm{BrC}-\mathrm{AAE}_{388 / 440 \mathrm{~nm}}$ is smaller than 2, the $388 \mathrm{~nm}$ AERONET AAOD distribution is sensitive to not only BrC-AAE $388 / 440 \mathrm{~nm}$ but also BC-AAE. Thus, by combining OMAERUV and AERONET AAOD data, we find that BrC-AAE $388 / 440 \mathrm{~nm}$ is typically $\sim 4$ globally but smaller $(<2)$ in Europe. These values are smaller than laboratory measurements of fresh emission from pyrolyzing wood by Chen and Bond, $2010\left(\mathrm{AAE}_{380 / 460 \mathrm{~nm}}>7\right)$ and biomass burning smoke by Kirchsteter et al. (2004) $\left(\mathrm{AAE}_{350 / 450 \mathrm{~nm}}=4.8\right)$. It should be mentioned that these AAE values are based on the $388-440 \mathrm{~nm}$ pair and may change for other wavelength pairs.

Many studies have evaluated OMAERUV AOD by comparing them with ground-based measurements. The correlation between OMAERUV and AERONET AOD is usually found to be high $(R>0.8)$ (Jethva and Torres, 2011; 
Ahn et al., 2014). Jethva et al. (2014) also compare the SSA between OMAERUV and AERONET and find $69 \%$ of the data agree within the absolute difference of \pm 0.05 for all aerosol types. Significant differences between the two datasets are most shown at dust-dominated sites. These dust-influenced sites are not included in our analysis. Furthermore, Jethva et al. (2014) compare these products at $440 \mathrm{~nm}$. The OMAERUV SSA estimated at this wavelength relies on a number of assumptions and is more uncertain than that reported at $388 \mathrm{~nm}$ that we use in our analysis. It is not possible to directly compare the SSA/AAOD at $388 \mathrm{~nm}$ since AERONET does not make measurements at this wavelength. Therefore, we believe that the comparison between AERONET and OMAERUV is still valid. However, if the OMAERUV SSA is higher or lower than AERONET at $388 \mathrm{~nm}$, our estimate of the $\mathrm{BrC}-\mathrm{AAE}_{388 / 440 \mathrm{~nm}}$ would be biased low or high.

\section{Surface multiple-wavelength absorption measurements}

\subsection{Sites and instruments}

In addition to the retrieved column AAOD from AERONET, we also use our method to derive the $\mathrm{BrC}$ absorption from direct measurements of absorption at a series of surface sites. Among the measurement methods for aerosol absorption, only the filter-based method using an Aethalometer (AE, Magee Scientific, http://www.mageesci.com) can be used to derive $\mathrm{BrC}$ absorption with our method. Aethalometers are designed to measure $\mathrm{BC}$ mass concentrations and can measure aerosol absorption at 7 wavelengths ranging from 370 to $950 \mathrm{~nm}$ (version AE-31). These seven wavelengths include more than two wavelengths at both UV and long wavelengths $(>600 \mathrm{~nm})$. As described in Sect. 2, our method requires absorption measurements in at least one wavelength in the near UV and another two measurements at wavelengths $>600 \mathrm{~nm}$. None of the other commercial instruments currently available meet this requirement.

As a filter-based method, Aethalometer measurements are known to exhibit artifacts from filter loading, filter scattering, and aerosol multiple scattering (Liousse et al., 1993; Collaud Coen et al., 2010). It is commonly thought that the absorption measurements from Aethalometers are biased towards much higher values (Arnott et al., 2005; Schmid et al., 2006). Although several correction algorithms have been published, many of these require additional information. Different correction methods may even lead to very different corrected results for the same original data (Schmid et al., 2006; Arnott et al., 2005; Collaud Coen et al., 2010; Weingartner et al., 2003). In our analyses of surface measurements, we will focus on the $\mathrm{BrC}$ absorption contribution and $\mathrm{BrC}-\mathrm{AAE}$, which are both ratios of AAOD. Following Sect. 2, the measurement bias on the absolute absorption will have minimal impact on the ratio unless there is a wavelength-dependent bias

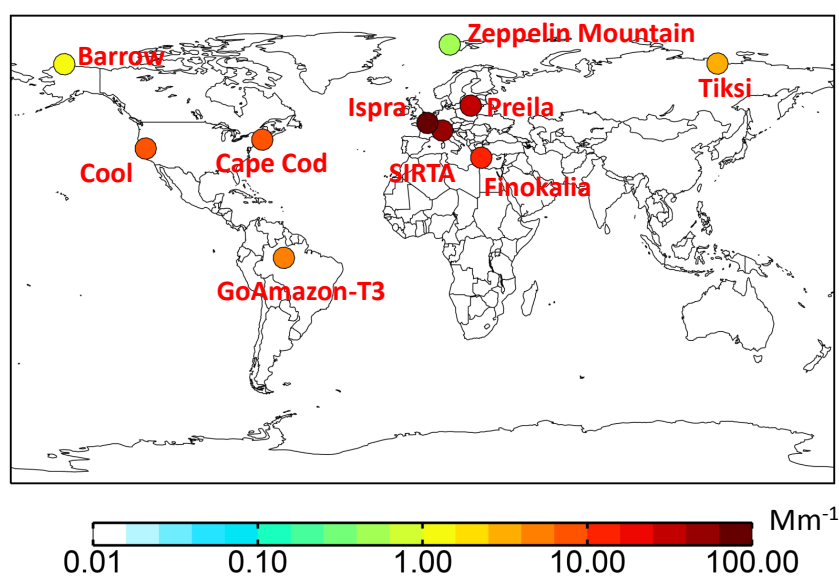

Figure 7. The locations of a series of field sites used in this study where multiple-wavelength absorption was measured using an Aethalometer. Each site is colored according to the mean aerosol absorption measured at $370 \mathrm{~nm}$. Values from the GoAmazon-T3 site are corrected, while others are uncorrected (see Sect. 4.1).

in the uncorrected data. By analyzing a series of different correction algorithms, Collaud Coen et al. (2010) conclude that it is not possible to precisely estimate the expected bias in AAE but that the corrected AAE is most likely to remain the same or increase slightly. In our $\mathrm{BrC}$ derivation method, a small change in AAE will not significantly impact the estimated WDA or the BrC contribution. Thus, we can apply our method to derive the $\mathrm{BrC}$ absorption contributions from the uncorrected multiple-wavelength absorption measured by Aethalometer. We also use these measurements to analyze the variation in $\mathrm{BrC}$ absorption at a single site, though the absolute values are likely biased high. The Aethalometer data are uncorrected in the following analyses except where noted.

Figure 7 shows the locations of the 10 surface sites we use in this analysis. These are Zeppelin Mountain in the Arctic, Barrow in Alaska, Tiksi in northern Siberia (on the shore of the Laptev Sea), Cool (near Sacramento in northern California) and Cape Cod (to the southeast of Boston) in the United States, Ispra in northern Italy, Preila in eastern Lithuania, SIRTA southwest of Paris in France, Finokalia in Greece (on the northeastern coast of the island of Crete), and the T3 site of the Observations and Modeling of the Green Ocean Amazon campaign (GoAmazon2014/5) to the west of Manaus in Brazil. Detailed information on these sites including measurement periods and references is given in Table 1. The absorption data from the GoAmazon-T3 site are provided with correction for filter loading and multiple-scattering effects using the methods outlined by Rizzo et al. (2011) and Schmid et al. (2006). 


\subsection{Estimated BrC absorption and AAE}

At Zeppelin Mountain and Cool, we detect little to no BrC absorption with our method. The Zeppelin Mountain site is very clean and aerosol absorption here is generally associated with long-range transport. The Cool site is located east of Sacramento, and as there were negligible biofuel or biomass burning emissions in July 2010, no major BrC sources are likely to impact this site. Br-SOA may contribute to the absorption at Cool, but it is below the detection limits of our method.

Figure 8 shows the monthly variation in the contribution of $\mathrm{BrC}$ to total aerosol absorption at $370 \mathrm{~nm}$ at the eight other sites. Since these eight sites are located in different environments from rural to urban, the chemical composition of OC is likely to be very different among these sites. However, the monthly mean contributions of $\mathrm{BrC}$ absorption at $370 \mathrm{~nm}$ occupy a relatively small range from 7 to $35 \%$. These numbers are smaller than the near-surface values (around 50\% at $365 \mathrm{~nm}$ ) estimated for a fire plume based on filter extracts from airborne measurements during the Deep Convective Clouds and Chemistry (DC3) campaign (J. Liu et al., 2015). It is possible that the $\mathrm{BrC}$ contribution is higher in such a concentrated plume compared to the well-mixed air represented by our monthly averages. In addition, while $\mathrm{BrC}$ absorption was measured directly during DC3, J. Liu et al. (2015) estimate of the contribution of BC to total absorption was based on the (possibly inaccurate) assumption that $\mathrm{BC}-\mathrm{AAE}=1$. The annual average total aerosol absorption at the urban site Ispra is nearly 120 times larger than the background site of Barrow in Alaska; however, $\mathrm{BrC}$ contributes comparable amounts to the total absorption at these sites. In Sect. 3.1, we showed similar $\mathrm{BrC}$ contributions of $<30 \%$ (at $440 \mathrm{~nm}$ ) at $80 \%$ of AERONET sites; the similar results obtained here from direct measurements of absorption support the analysis of the AERONET data despite concerns about data quality and retrieval assumptions. It is likely that the proportion of $\mathrm{BC}$ absorption and $\mathrm{BrC}$ absorption does not differ substantially among regions even though the emission sources are very different. This is consistent with our speculation in Sect. 3.2 that the MAC of OC is related to the combustion properties and positively correlated with $\mathrm{BC} / \mathrm{OC}$ emission ratio. Because higher OC-MAC is usually associated with higher $\mathrm{BC} / \mathrm{OC}$ mass ratio, the absorption ratio of $\mathrm{BC} / \mathrm{OC}$ may be roughly constant if BC-MAC is relatively constant. This ensures that the proportion of $\mathrm{BC}$ to $\mathrm{BrC}$ absorption does not vary much among different sources. Small seasonal variations in the fractional contribution of $\mathrm{BrC}$ absorption are seen at the sites of Finokalia and SIRTA (Fig. 8b and c). At these two sites, $\mathrm{BrC}$ contributes more absorption in winter than in summer. This is also similar to the analysis of the AERONET observations; however, these variations are not large and the monthly mean $\mathrm{BrC}$ absorption contributions remain in the $10-30 \%$ range. This winter shift is likely to be associated with the residential heating from biofuel combus-

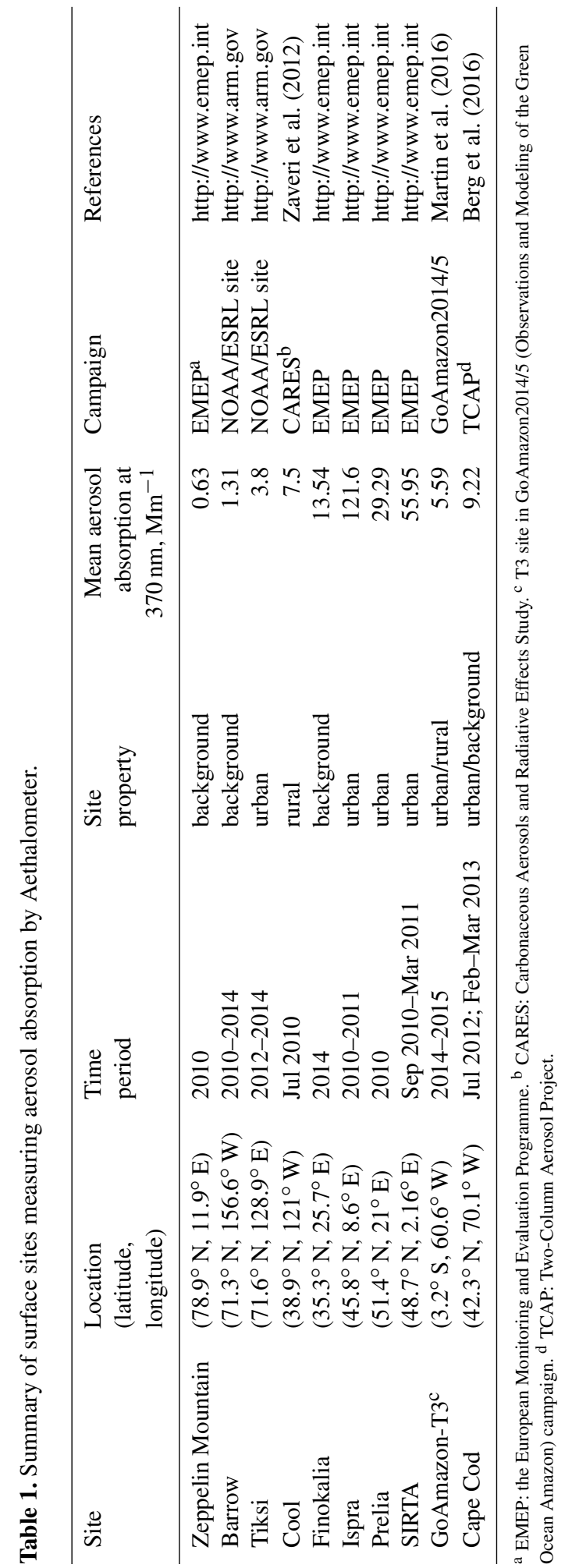

Atmos. Chem. Phys., 16, 12733-12752, 2016 

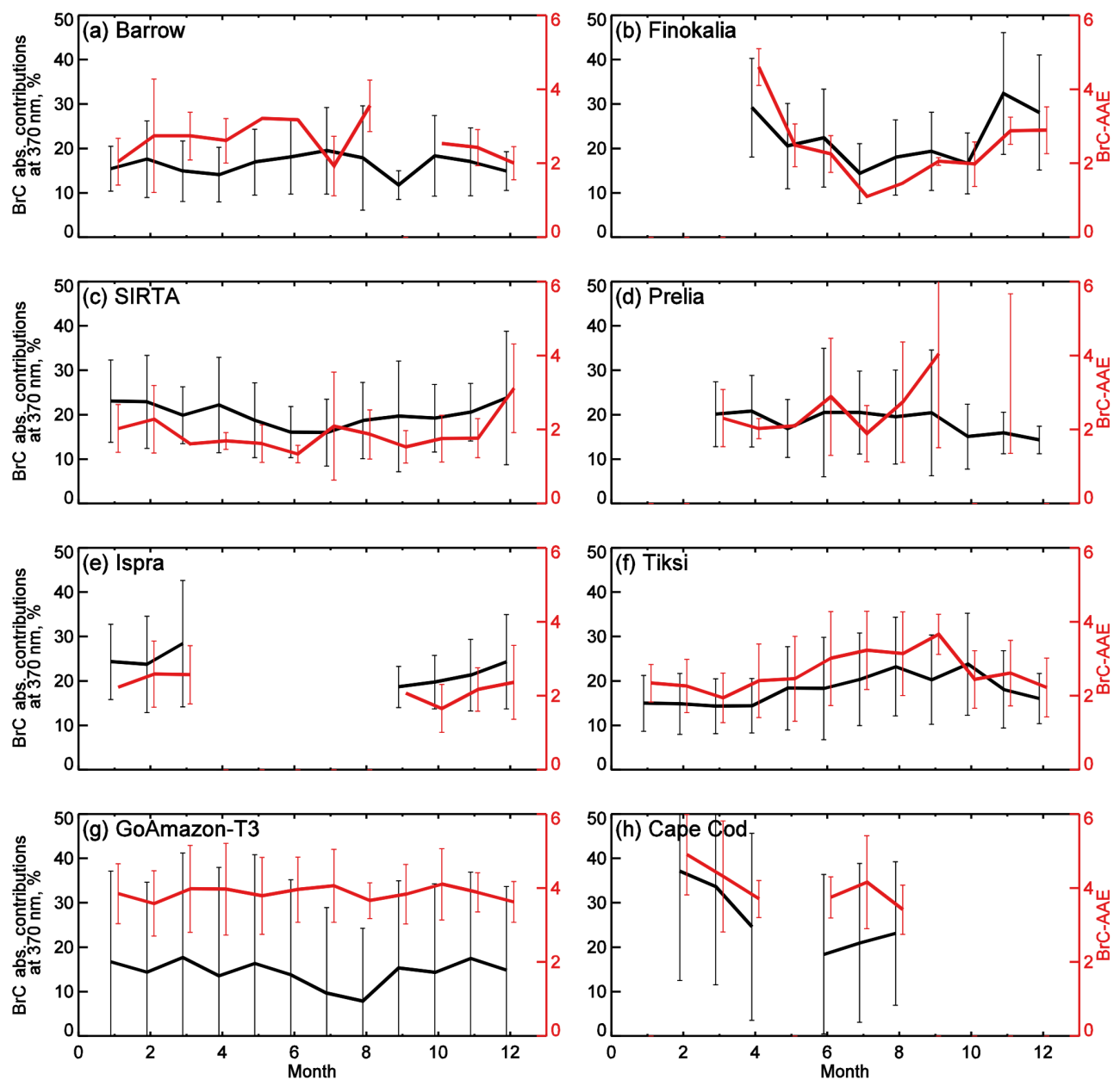

Figure 8. Monthly variation in the derived $\mathrm{BrC}$ contribution to total absorption at $370 \mathrm{~nm}$ (black) and BrC-AAE (red) at a series of surface sites (see Table 1, Fig. 7). The BrC-AAE in (g) GoAmazon-T3 site and (h) Cape Cod is calculated using the 370-430 nm wavelength pair, while that at other sites is based on the $370-470 \mathrm{~nm}$ wavelength pair. Error bars indicate the standard deviation for values averaged in each month.

tion. The $\mathrm{BC} / \mathrm{OC}$ ratio for biofuel emissions from residential heating is typically lower than other sources (Streets et al., 2004). However, given the variability in BC-MAC, it is not clear whether this lower $\mathrm{BC} / \mathrm{OC}$ mass ratio is the dominant reason for the winter shift.

The contribution of $\mathrm{BrC}$ absorption changes with wavelength. Considering the influence of the $\mathrm{AAE}$ of both $\mathrm{BC}$ and $\mathrm{BrC}$, the contribution of $\mathrm{BrC}$ at $370 \mathrm{~nm}$ should be a little larger than at $440 \mathrm{~nm}$. For example, with $\mathrm{BrC}-\mathrm{AAE}=4$, a $20 \% \mathrm{BrC}$ absorption contribution at $370 \mathrm{~nm}$ will decrease to $13 \%$ at $440 \mathrm{~nm}$ and $7 \%$ at $550 \mathrm{~nm}$. By comparing the results from these eight sites with the nearest AERONET sites, we find that the $\mathrm{BrC}$ absorption contributions at $370 \mathrm{~nm}$ at the surface are similar to the column BrC-AAOD contributions at $440 \mathrm{~nm}$ from AERONET. This may suggest that the $\mathrm{BrC}$ absorption contribution increases with altitude. This vertical difference was also identified in analysis of the DC3 airborne observations (J. Liu et al., 2015). Alternatively, it may sug- gest a high bias in the BrC estimated from AERONET observations.

Figure 8 also shows the estimated $\mathrm{AAE}_{370 / 430 \mathrm{~nm}}$ of $\mathrm{BrC}$ from Aethalometer observations. Generally, the monthly mean $\mathrm{BrC}-\mathrm{AAE}_{370 / 430 \mathrm{~nm}}$ at these eight sites ranges from 2 to 4 . Low BrC-AAE $(<2)$ is frequently observed at the three European sites of SIRTA, Prelia, and Ispra (Fig. 8c, d, and e), consistent with the analysis of AERONET and OMI measurements over Europe. At most of the sites (Fig. 8a, b, c, $\mathrm{f}$, and $\mathrm{h}$ ), the monthly variations in $\mathrm{BrC}-\mathrm{AAE}_{370 / 430 \mathrm{~nm}}$ are similar to the variation in the $\mathrm{BrC}$ absorption contributions. As described above, an increase in $\mathrm{BrC}$ absorption contribution may be due to either an increase in OC-MAC or a decrease in the $\mathrm{BC} / \mathrm{OC}$ mass ratio. This suggests the $\mathrm{BrC}-$ $\mathrm{AAE}_{370 / 430 \mathrm{~nm}}$ is either positively correlated with OC-MAC or negatively correlated with $\mathrm{BC} / \mathrm{OC}$ emission ratio. The latter case was observed in the laboratory study of Saleh et al. (2014). However, the correlations between BrC-AAE 

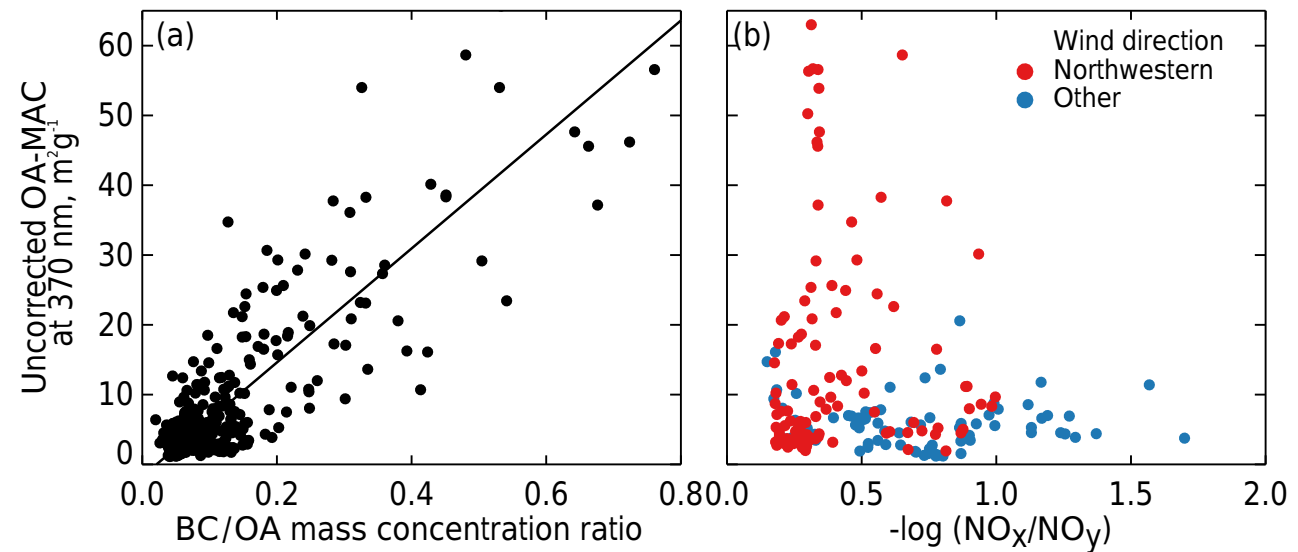

Figure 9. Measurements from the TCAP campaign in Cape Cod in February 2013. The relationship between uncorrected OA-MAC measured at $370 \mathrm{~nm}$ and (a) the observed BC / OA ratio, as well as (b) the measured photochemical clock. All values are hourly means. The colors in (b) indicate different wind directions discussed in Sect. 4.3.

and $\mathrm{BrC}$ absorption contributions are only slight to moderate $\left(R^{2}<0.3\right)$ at these sites.

\subsection{Estimating the evolution of OA-MAC}

To better understand the absorption properties of $\mathrm{BrC}$ and eliminate the influence of aerosol mass, analysis of both $\mathrm{BrC}$ absorption and OA mass are necessary. Additional measurements of OA mass are available at two of our eight sites (Cape Cod and GoAmazon-T3).

At the Cape Cod site during the TCAP campaign, the refractory black carbon $(\mathrm{rBC})$ and $\mathrm{OA}$ mass were measured using a single-particle soot photometer (SP2; Schwarz et al., 2008) and a high resolution time-of-flight aerosol mass spectrometer (HR-ToF-AMS; Canagaratna et al., 2007) in February 2013. With both derived BrC absorption and measured OA mass, OA-MAC can be directly estimated. As discussed in Sect. 4.1, the OA-MAC derived from uncorrected Aethalometer data are biased high, but the relative variation can be used in the analysis. These data are used to examine the influence of emission properties and chemical processing on the absorption properties of $\mathrm{BrC}$. To identify the impact of emission properties on OA-MAC, we compare OA-MAC with the co-measured BC / OC mass ratio (Fig. 9a). These are highly correlated $\left(R^{2}=0.75\right)$, which further confirms the previously discussed relationship between OA-MAC and $\mathrm{BC} / \mathrm{OC}$ ratio.

The observations at Cape Cod also provide the opportunity to identify whether there is any relationship between $\mathrm{BrC}$ absorption and chemical processing during transport. In laboratory studies, both increases in OA-MAC from new $\mathrm{BrC}-\mathrm{OA}$ generation and decreases in OA-MAC from BrCOA photolysis (bleaching) have been observed (Laskin et al., 2015; Lee et al., 2014; Flores et al., 2014). The only previous field observations of chemical processing of $\mathrm{BrC}$ by Forrister et al. (2015) found that photolysis decreases the MAC of biomass-burning-sourced $\mathrm{BrC}$, but the rate of change is much slower than previously estimated from laboratory experiments. Here we use the quantity of $-\log \left(\mathrm{NO}_{x} / \mathrm{NO}_{y}\right)$ as a photochemical clock. Assuming the photochemical rate of converting $\mathrm{NO}_{x}\left(\mathrm{NO}+\mathrm{NO}_{2}\right)$ to total reactive nitrogen $\left(\mathrm{NO}_{y}\right)$ is equal to the reaction between $\mathrm{NO}_{2}$ and $\mathrm{OH}$, this photochemical clock can be seen as a measure of chemical processing since emission (Kleinman et al., 2008). The OAMAC is plotted versus this photochemical clock in Fig. 9b, colored according to wind direction. The data points from TCAP in February can be divided into two groups according to wind direction: the first group includes those with winds from the northwest (red points in Fig. 9b), which are mostly affected by transported urban air from Boston; the remaining data which represent background air masses are shown as a second group (blue points in Fig. 9b). The OA-MAC, as well as the mass concentrations of both $\mathrm{BC}$ and $\mathrm{OA}$, for the data from the northwest is generally larger than the other group due to the influence of fresher urban emissions. We can see from Fig. 9b that this source difference dominates the variation in OA-MAC. For either individual group, we find no significant trend with photochemical clock. Our analysis shows that the OA-MAC neither increases nor decreases with increasing aging time in background or urban air masses. This suggests either that the generation and photolysis of $\mathrm{BrC}$ counteract each other or that the influence from chemical processing is much smaller than emissions and transport for these observations. However, we note that these wintertime measurements are not optimal for identifying any photochemical processing; additional measurements in multiple seasons are required.

We repeat the analysis applied at the Cape Cod site to the observations from the GoAmazon-T3 site in the Amazon. Mass concentrations of $\mathrm{BC}$ and $\mathrm{OA}$ were measured at this site using an SP2 and an HR-ToF-AMS (de Sá et al., personal communication, 2016) during two intensive operat- 

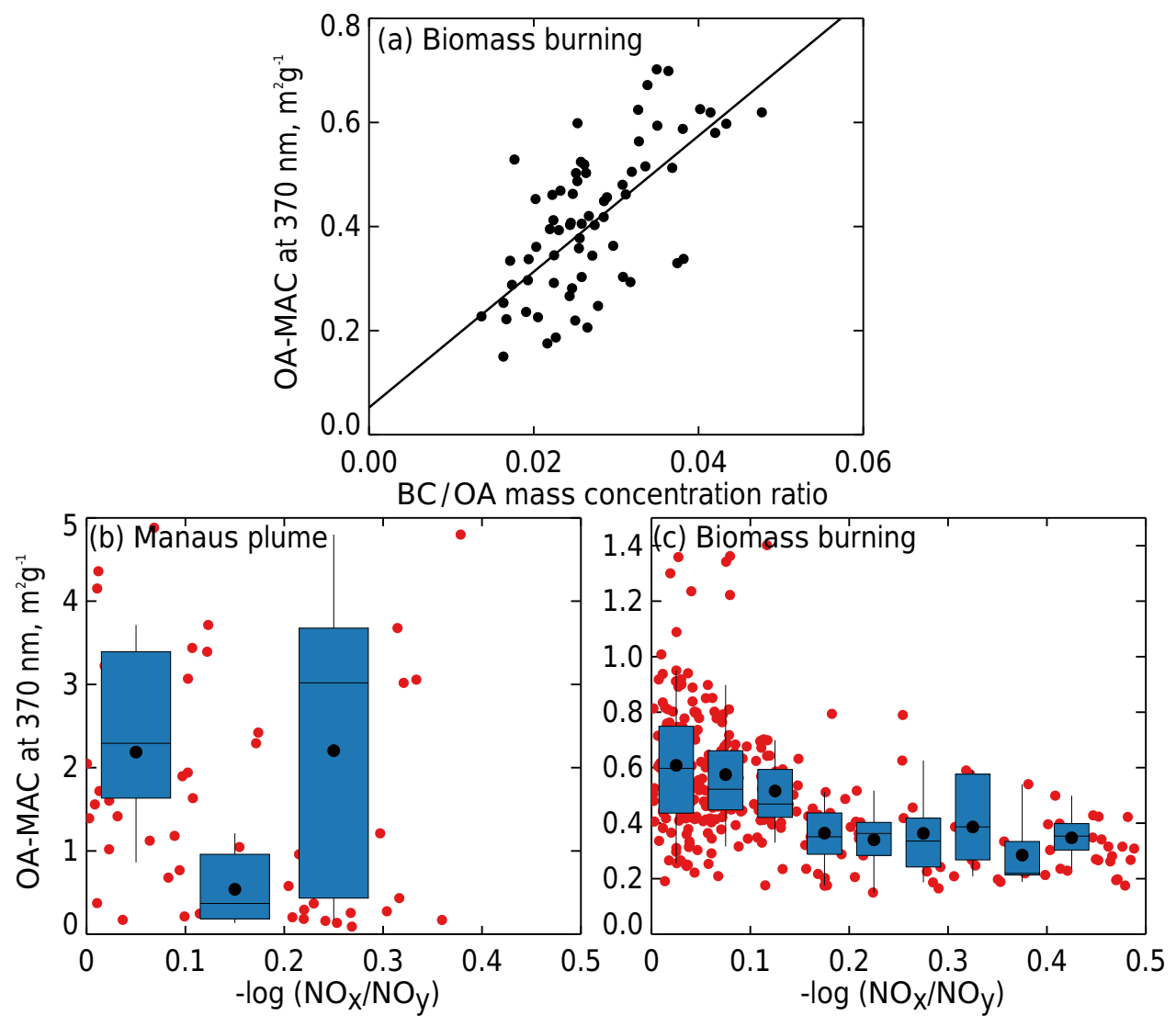

Figure 10. Measurements from the GoAmazon2014/5 campaign at the T3 site, to the west of Manaus, Brazil. The relationship between hourly mean BrC-MAC measured at $370 \mathrm{~nm}$ and (a) the observed BC / OA ratio during 15 August-15 October 2014 (IOP2), as well as (b) the measured photochemical clock during January-March 2015 with selected Manaus plumes and (c) IOP2, excluding Manaus plumes. In (b) and (c), the red points are individual hourly average measurements, whereas the box-and-whisker plots show the binned mean (black points), median (black lines inside boxes), lower and upper quartile (boxes), and 5th and 95th percentile (whiskers).

ing periods (IOPs). IOP1 took place in the wet season, from 1 February to 31 March, and IOP2 occurred during the dry season, from 15 August to 15 October, both in 2014. Unfortunately, data availability for $\mathrm{BC}$ and $\mathrm{NO}_{x}$ concentrations are poor during IOP1. We therefore supplement our analysis with Aerosol Chemical Speciation Monitoring (ACSM) measurements of OA from January to March 2015. During this time period the sources of OA at the T3 site are generally from the city of Manaus and the forested region around it, with very low incidence of fires. IOP2 occurs during the biomass burning season and the T3 site is highly influenced by fires during this period (Martin et al., 2015). Figure 10a shows that the measured OA-MAC and the $\mathrm{BC} / \mathrm{OC}$ ratio during IOP2 are correlated $\left(R^{2}=0.5\right)$ at this site as well.

Figure $10 \mathrm{~b}$ and $\mathrm{c}$ compare the measured OA-MAC with the photochemical clock $-\log \left(\mathrm{NO}_{x} / \mathrm{NO}_{y}\right)$ at the GoAmazon-T3 site under low biomass burning (JanuaryMarch 2015) and high biomass burning (IOP2) influence. During the low biomass burning season, we select the daytime data from Manaus only (based on wind direction from the east) to eliminate the potential contamination of the photochemical clock from biogenic $\mathrm{NO}_{x}$ emissions around the site. In contrast, we exclude the Manaus plume-related data points during the high biomass burning season (IOP2) to ensure that the analysis reflects only the near-field (fresh) and far-field (aged) fires. The results presented here are not strongly sensitive to this data filtering. However, we acknowledge that recirculation in the basin surrounding the T3 site may complicate the quantitative interpretation of the photochemical clock. Figure 10b demonstrates that, under urban influence, there is little evidence for a decrease in $\mathrm{BrC}$ absorption due to photochemical processing, similar to our results from Cape Cod. However, during the biomass burning season we observe a clear decrease in OA-MAC with increasing aging time (Fig. 10c). This suggests that the absorption of OA emitted from biomass burning decreases due to photolysis or oxidation of $\mathrm{BrC}$. We note that the total mass of OA does not increase or decrease significantly with increasing aging time; therefore, while we cannot definitively rule out the formation of SOA during transit lead- 
ing to a "whitening" of total OA, the observations do not suggest that this is a major effect. The binned median OAMAC values in Fig. $10 \mathrm{c}$ can be fitted exponentially with $-\log \left(\mathrm{NO}_{x} / \mathrm{NO}_{y}\right)\left(R^{2}=0.95\right)$. By assuming the oxidation rate of $\mathrm{NO}_{2}$ to be $1.05 \times 10^{-11} \mathrm{~cm}^{3} \mathrm{~mol}^{-1} \mathrm{~s}^{-1}$ at $01.00 \mathrm{~atm}$ and $300 \mathrm{~K}$ (Sander et al., 2011) and typical daytime $\mathrm{OH}$ concentration of $5 \times 10^{5} \mathrm{~mol} \mathrm{~cm}^{-3}$ we estimate an $e$-folding time and half-life for the OA absorption to be 22 daytime hours and 14 daytime hours, respectively (or 45 and $30 \mathrm{~h}$, assuming zero nighttime $\mathrm{OH}$ extending $13 \mathrm{~h}$ of the day during IOP2). Since the biomass burning emissions during IOP2 are frequent and disperse, it is not clear how much of the transport of biomass burning plumes from source to the $\mathrm{T} 3$ site occurs at night. These calculated lifetimes neglect other losses of $\mathrm{NO}_{x}$ and are highly sensitive to the assumed $\mathrm{OH}$ concentration; at extremely high $\left(\sim 10^{7} \mathrm{~mol} \mathrm{~cm}^{-3}\right)$ or lower $\left(\sim 10^{5} \mathrm{~mol} \mathrm{~cm}^{-3}\right) \mathrm{OH}$ concentrations, the half-life in sunlight would be calculated to be $1 \mathrm{~h}$ or 3.5 days. If the $\mathrm{OH}$ concentration in the measurement period is, as assumed here, similar to typical global mean values (Stone et al., 2012), the half-life is comparable to the biomass burning plume observed by Forrister et al. (2015) (9-15 h). However, this halflife would be significantly longer than estimated in laboratory studies which have focused on SOA aging ( $5 \mathrm{~min}$ to $3 \mathrm{~h}$ ), suggesting that additional laboratory studies are necessary to examine the aging of $\mathrm{BrC}$ from biomass burning. We also observe that the $\mathrm{BrC}$ absorption does not appear to decrease to 0 with continued aging $(>15 \mathrm{~h})$ in our analysis. This is also consistent with Forrister et al. (2015), who suggest that sunlight shows no effect on $\mathrm{BrC}$ absorption after about $12 \mathrm{~h}$ of continuous exposure. This may results in a persistent $\mathrm{BrC}$ background from fire emissions, even after aging.

\section{Discussion}

By using a new method to derive $\mathrm{BrC}$ absorption we identify consistent $\mathrm{BrC}$ characteristics from both the global AERONET sun photometer network and 8 surface sites. At most sites, the $\mathrm{BrC}$ absorption contribution in the UV ranges from 10 to $30 \%$. This range of $\mathrm{BrC}$ absorption contribution can be used to constrain model simulations or provide a rough estimate of $\mathrm{BrC}$ based on measured $\mathrm{BC}$.

The relatively consistent contribution of $\mathrm{BrC}$ to total absorption can be explained by the correlation between $\mathrm{OC}$ MAC and the BC / OC mass ratio, which is observed at both AERONET and surface measurement sites. As our analysis shows that higher OC-MAC is found to be associated with lower OC mass contribution in the atmosphere, the $\mathrm{BrC}$ absorption contribution lies within a narrow range globally despite differences in the emission. Based on this correlation and $\mathrm{BC} / \mathrm{OC}$ emission ratios, we estimate a range of MAC: $0.1-3.1 \mathrm{~m}^{2} \mathrm{~g}^{-1}$ for OC and $0.05-1.5 \mathrm{~m}^{2} \mathrm{~g}^{-1}$ for $\mathrm{OA}$ at $440 \mathrm{~nm}$ from AERONET observations when assuming $\mathrm{OA} / \mathrm{OC}=2.1$. This correlation also suggests the $\mathrm{BC} / \mathrm{OC}$ emission ratio could provide important information for build- ing an emission inventory for $\mathrm{BrC}$. However, our analysis is based on ambient measurements of BC / OC absorption ratios, and extrapolation of these results to emissions requires further investigation of how the $\mathrm{BC} / \mathrm{OC}$ ratio changes (via chemistry, transport, and removal) from source to ambient measurement. Further laboratory studies which include both $\mathrm{BrC}$ and $\mathrm{BC}$ measurements are required to examine how $\mathrm{BrC}$ absorption varies with emission properties.

The BrC-AAE $388 / 440 \mathrm{~nm}$ that we estimate from AERONET and OMI measurements is also very similar to that which we derive from surface in situ measurements. Both analyses suggest that the global mean BrC-AAE $388 / 440 \mathrm{~nm}$ is likely to be $\sim 4$. However, lower $\mathrm{AAE}_{388 / 440 \mathrm{~nm}}(<2)$ are found in Europe from both surface measurements and AERONET sites, suggesting that the $\mathrm{BrC}$ in Europe may exhibit different optical properties. These BrC-AAE values are within the range of 1.9 to 9 measured in laboratory experiments (Laskin et al., 2015). However, these results are based on different wavelength pairs and are therefore not directly comparable. In addition, many of the laboratory reported values typically rely on one long wavelength in the visible spectrum (e.g. $\mathrm{AAE}_{370 / 660 \mathrm{~nm}}$ or $\mathrm{AAE}_{330 / 600 \mathrm{~nm}}$ ). Since $\mathrm{BrC}$ absorption at these long wavelengths is too small to be detected accurately, these BrC-AAE are likely quite uncertain.

For well-mixed air masses exposed to urban emissions, our analysis of the observations at Cape Cod in February and at GoAmazon-T3 site in the non-biomass burning season do not provide any evidence for evolving $\mathrm{BrC}$ optical properties associated with photolysis or oxidation. It may be either that the chemistry impact is not as significant as emissions/transport or that the photolysis and generation of $\mathrm{BrC}$ counteract each other. In contrast, the observations at GoAmazon-T3 site during the biomass burning season exhibit a $\sim 1$-day photochemical lifetime (in sunlight) for $\mathrm{BrC}$ absorption. This decrease in absorption is qualitatively consistent with previous field observations (Forrister et al., 2015) and may suggest that the absorption of $\mathrm{BrC}$ from fire emissions is geographically limited to the near field. This may also explain the somewhat counterintuitive lack of strong $\mathrm{BrC}$ signature in biomass burning regions/seasons in our analysis of AERONET observations (Fig. 3). The majority of studies which have investigated the "browning" or "whitening" of $\mathrm{BrC}$ have focused on laboratory experiments at extreme conditions; however, the chemical processes in the real atmosphere may be very different from these controlled environments. Additional laboratory and field studies of how the optical properties of primary $\mathrm{BrC}$ may evolve due to photooxidation are required.

Using $\mathrm{BrC}-\mathrm{AAE}=4$ as suggested by our analysis of AERONET and OMI satellite observations, the $\mathrm{BrC}$ column absorption contribution is $0-40 \%$ at $440 \mathrm{~nm}$ and less than $20 \%$ at $550 \mathrm{~nm}$. This suggests that the previous model estimated BrC absorption DRE contributions (20-40\%) are likely to be biased slightly high (Feng et al., 2013; Lin et al., 
2014). Including photochemical "whitening" of $\mathrm{BrC}$ from fires in these models may resolve these discrepancies.

By applying a new AAE method that we describe in this paper, we have obtained global observational constraints on $\mathrm{BrC}$ absorption. However, these results are subject to uncertainties associated both with the methodology and with the dataset to which it is applied. The core issue for all methods that use the AAE to estimate the absorption from $\mathrm{BrC}$ is the uncertainty associated with the absorption of BC. Our method improves upon previous studies using this approach by using the information from the wavelength-dependent measurements themselves and by allowing for an atmospherically relevant range of $\mathrm{BC}$ properties, rather than fixing these at a single assumed value. Additional constraints on BC optical properties and mixing state would help further improve the method.

Given the large uncertainties associated with AERONET retrievals of $\mathrm{AAOD}$, the most challenging aspect of our analysis is that an accurate, globally distributed, multiplewavelength aerosol absorption measurement dataset is unavailable at present. Thus, while our study provides qualitative global constraints and insight into $\mathrm{BrC}$ aging processes from the Aethalometer observations, achieving a better understanding of the properties, evolution, and impacts of global BrC will rely on the future deployment of accurate multiple-wavelength absorption measurements to which AAE methods, such as the approach developed here, can be applied.

\section{Data availability}

The AERONET data are freely available online at http: //aeronet.gsfc.nasa.gov/ (NASA, 2016). The OMAERUV product is available online on the Goddard Earth Sciences Data and Information Services Center (GES DISC, 2016) web page: http://disc.sci.gsfc.nasa.gov/Aura/data-holdings/ OMI/. The data from the GoAmazon2014/5 campaign, CARES campaign and TCAP campaign are available online at ARM's Data Discovery (ARM, 2016) browser: http:// www.archive.arm.gov/discovery/\#v/home/s/. The data from the EMEP and NOAA/ESRL sites are accessible online on the World Data Centre for Aerosols web page: http://ebas. nilu.no/ (EBAS, 2016).

Acknowledgements. This work was supported by the EPA-STAR program. Although the research described in this article was funded in part by the US EPA through grant/cooperative agreement RD-83503301, it has not been subjected to the EPA's required peer and policy review and therefore does not necessarily reflect the views of the EPA and no official endorsement should be inferred. The GoAmazon2014/5 and TCAP data were obtained from the Atmospheric Radiation Measurement (ARM) Climate Research Facility, a US Department of Energy Office of Science user facility sponsored by the Office of Biological and Environmental Research.
For the GoAmazon2014/5 data, we also acknowledge the support from the Central Office of the Large Scale Biosphere Atmosphere Experiment in Amazonia (LBA), the Instituto Nacional de Pesquisas da Amazônia (INPA), and the Universidade do Estado do Amazonia (UEA). The work of GoAmazon2014/5 campaign was conducted under 001030/2012-4 of the Brazilian National Council for Scientific and Technological Development (CNPq). The AMS measurement at GoAmazon2014/5-T3 site was performed using EMSL, a DOE Office of Science User Facility sponsored by the Office of Biological and Environmental Research and located at Pacific Northwest National Laboratory. We thank Jesse Kroll, Eleanor Browne, Kelsey Boulanger, Anthony Carasquillo, and Kelly Daumit for AMS measurement during TCAP. We also thank the Norwegian Institute for Air Research (NILU) and the NOAA Earth System Research Laboratory for providing the EMEP and NOAA/ESRL background site measurements, as well as the AERONET staff for establishing and maintaining the sun photometer network used in this study.

Edited by: U. Pöschl

Reviewed by: four anonymous referees

\section{References}

Adachi, K., Chung, S. H., and Buseck, P. R.: Shapes of soot aerosol particles and implications for their effects on climate, J. Geophys. Res., 115, D15206, doi:10.1029/2009JD012868, 2010.

Ahn, C., Torres, O., and Jethva, H.: Assessment of OMI near-UV aerosol optical depth over land, J. Geophys. Res.-Atmos., 119, 2457-2473, 2014.

Aiken, A. C., Decarlo, P. F., Kroll, J. H., Worsnop, D. R., Huffman, J. A., Docherty, K. S., Ulbrich, I. M., Mohr, C., Kimmel, J. R., Sueper, D., Sun, Y., Zhang, Q., Trimborn, A., Northway, M., Ziemann, P. J., Canagaratna, M. R., Onasch, T. B., Alfarra, M. R., Prevot, A. S. H., Dommen, J., Duplissy, J., Metzger, A., Baltensperger, U., and Jimenez, J. L.: O / C and OM / OC ratios of primary, secondary, and ambient organic aerosols with high-resolution time-of-flight aerosol mass spectrometry, Environ. Sci. Technol., 42, 4478-4485, 2008.

Akagi, S. K., Craven, J. S., Taylor, J. W., McMeeking, G. R., Yokelson, R. J., Burling, I. R., Urbanski, S. P., Wold, C. E., Seinfeld, J. H., Coe, H., Alvarado, M. J., and Weise, D. R.: Evolution of trace gases and particles emitted by a chaparral fire in California, Atmos. Chem. Phys., 12, 1397-1421, doi:10.5194/acp-12-13972012, 2012.

Alexander, D. T. L., Crozier, P. A., and Anderson, J. R.: Brown Carbon Spheres in East Asian Outflow and Their Optical Properties, Science, 321, 833-836, 2008.

ARM: GoAmazon2014/5 campaign, CARES campaign and TCAP campaign, available at: http://www.archive.arm.gov/discovery/ \#v/home/s/, last access: 12 October 2016.

Arnott, W., Hamasha, K., Moosmüller, H., Sheridan, P. J., and Ogren, J. A.: Towards aerosol light-absorption measurements with a 7-wavelength aethalometer: Evaluation with a photoacoustic instrument and 3-wavelength nephelometer, Aerosol Sci. Tech., 39, 17-29, 2005.

Arola, A., Schuster, G., Myhre, G., Kazadzis, S., Dey, S., and Tripathi, S. N.: Inferring absorbing organic carbon content 
from AERONET data, Atmos. Chem. Phys., 11, 215-225, doi:10.5194/acp-11-215-2011, 2011.

Artaxo, P., Rizzo, L. V., Brito, J. F., Barbosa, H. M., Arana, A., Sena, E. T., Cirino, G. G., Bastos, W., Martin, S. T., and Andreae, M. O.: Atmospheric aerosols in Amazonia and land use change: from natural biogenic to biomass burning conditions, Faraday Discuss., 165, 203-235, 2013.

Bahadur, R., Praveen, P. S., Xu, Y., and Ramanathan, V.: Solar absorption by elemental and brown carbon determined from spectral observations, P. Natl. Acad. Sci. USA, 109, 17366-17371, 2012

Berg, L. K., Fast, J. D., Barnard, J. C., Burton, S. P., Cairns, B., Chand, D., Comstock, J. M., Dunagan, S., Ferrare, R. A., Flynn, C. J., Hair, J. W., Hostetler, C. A., Hubbe J., Jefferson, A., Johnson, R., Kassianov, E. I., Kluzek, C. D., Kollias, P., Lamer, K., Lantz, K., Mei, F., Miller, M. A., Michalsky, J., Ortega, I., Pekour, M., Rogers, R. R., Russell, P. B., Redemann, J., Sedlacek III, A. J., Segal-Rosenheimer, M., Schmid, B., Shilling, J. E., Shinozuka, Y., Springston, S. R., Tomlinson, J. M., Tyrrell, M., Wilson, J. M., Volkamer, R., Zelenyuk, A., and Berkowitz, C. M.: The Two-Column Aerosol Project: Phase I - Overview and impact of elevated aerosol layers on aerosol optical depth, J. Geophys. Res.-Atmos., 121, 336-361, 2016.

Bond, T. C. and Bergstrom, R. W.: Light absorption by carbonaceous particles: an investigative review, Aerosol Sci. Tech., 40, 27-67, 2006.

Bond, T. C., Bhardwaj, E., Dong, R., Jogani, R., Jung, S. K., Roden, C., Streets, D. G., and Trautmann, N. M.: Historical emissions of black and organic carbon aerosol from energy-related combustion, 1850-2000, Global Biogeochem. Cy., 21, GB2018, doi:10.1029/2006GB002840, 2007.

Bond, T. C., Doherty, S., Fahey, D., Forster, P., Berntsen, T., DeAngelo, B., Flanner, M., Ghan, S., Kärcher, B., and Koch, D.: Bounding the role of black carbon in the climate system: A scientific assessment, J. Geophys. Res.-Atmos., 118, 5380-5552, 2014.

Bueno, P. A., Havey, D. K., Mulholland, G. W., Hodges, J. T., Gillis, K. A., Dickerson, R., and Zachariah, M. R.: Photoacoustic Measurements of Amplification of the Absorption Cross Section for Coated Soot Aerosols, Aerosol Sci. Tech., 45, 1217-1230, 2011.

Canagaratna, M. R., Jayne, J. T., Jimenez, J. L., Allan, J. D., Alfarra, M. R., Zhang, Q., Onasch, T. B., Drewnick, F., Coe, H., Middlebrook, A., Delia, A., Williams, L. R., Trimborn, A. M., Northway, M. J., DeCarlo, P. F., Kolb, C. E., Davidovits, P., and Worsnop, D. R.: Chemical and microphysical characterization of ambient aerosols with the aerodyne aerosol mass spectrometer, Mass Spectrom. Rev., 26, 185-222, 2007.

Cappa, C. D., Onasch, T. B., Massoli, P., Worsnop, D. R., Bates, T. S., Cross, E. S., Davidovits, P., Hakala, J., Hayden, K. L., Jobson, B. T., Kolesar, K. R., Lack, D. A., Lerner, B. M., Li, S.-M., Mellon, D., Nuaaman, I., Olfert, J. S., Petäjä, T., Quinn, P. K., Song, C., Subramanian, R., Williams, E. J., and Zaveri, R. A.: Radiative Absorption Enhancements Due to the Mixing State of Atmospheric Black Carbon, Science, 337, 1078-1081, 2012.

Chakrabarty, R. K., Moosmüller, H., Chen, L.-W. A., Lewis, K., Arnott, W. P., Mazzoleni, C., Dubey, M. K., Wold, C. E., Hao, W. M., and Kreidenweis, S. M.: Brown carbon in tar balls from smoldering biomass combustion, Atmos. Chem. Phys., 10, 63636370, doi:10.5194/acp-10-6363-2010, 2010.
Chen, Y. and Bond, T. C.: Light absorption by organic carbon from wood combustion, Atmos. Chem. Phys., 10, 1773-1787, doi:10.5194/acp-10-1773-2010, 2010.

Chung, C. E., Ramanathan, V., and Decremer, D.: Observationally constrained estimates of carbonaceous aerosol radiative forcing, P. Natl. Acad. Sci. USA, 109, 11624-11629, 2012.

Clarke, A., McNaughton, C., Kapustin, V., Shinozuka, Y., Howell, S., Dibb, J., Zhou, J., Anderson, B., Brekhovskikh, V., Turner, H., and Pinkerton, M.: Biomass Burning and Pollution Aerosol over North America: Organic Components and Their Influence on Spectral Optical Properties and Humidification Response, J Geophys. Res., 112, D12S18, doi:10.1029/2006jd007777, 2007.

Collaud Coen, M., Weingartner, E., Apituley, A., Ceburnis, D., Fierz-Schmidhauser, R., Flentje, H., Henzing, J. S., Jennings, S. G., Moerman, M., Petzold, A., Schmid, O., and Baltensperger, U.: Minimizing light absorption measurement artifacts of the Aethalometer: evaluation of five correction algorithms, Atmos. Meas. Tech., 3, 457-474, doi:10.5194/amt-3-457-2010, 2010.

Dubovik, O. and M. D. King: A flexible inversion algorithm for retrieval of aerosol optical properties from Sun and sky radiance measurements, J. Geophys. Res., 105, 20673-20696, 2000.

Dubovik, O., Holben, B., Eck, T. F., Smirnov, A., Kaufman, Y. J., King, M. D., Tanre, D., and Slutsker, I.: Variability of absorption and optical properties of key aerosol types observed in worldwide locations, J. Atmos. Sci., 59, 590-608, 2002.

EBAS: EMEP and NOAA/ESRL site data, available at: http://ebas. nilu.no/, last access: 12 October 2016.

Ervens, B., Turpin, B. J., and Weber, R. J.: Secondary organic aerosol formation in cloud droplets and aqueous particles (aqSOA): a review of laboratory, field and model studies, Atmos. Chem. Phys., 11, 11069-11102, doi:10.5194/acp-1111069-2011, 2011.

Feng, Y., Ramanathan, V., and Kotamarthi, V. R.: Brown carbon: a significant atmospheric absorber of solar radiation?, Atmos. Chem. Phys., 13, 8607-8621, doi:10.5194/acp-13-8607-2013, 2013.

Flores, J. M., Washenfelder, R. A., Adler, G., Lee, H. J., Segev, L., Laskin, J., Laskin, A., Nizkorodov, S. A., Brown, S. S., and Rudich, Y.: Complex refractive indices in the near-ultraviolet spectral region of biogenic secondary organic aerosol aged with ammonia, Phys. Chem. Chem. Phys., 16, 10629-10642, 2014.

Forrister, H., Liu, J., Scheuer, E., Dibb, J., Ziemba, L., Thornhill, K. L., Anderson, B., Diskin, G., Perring, A. E., Schwarz, J. P., Campuzano-Jost, P., Day, D. A., Palm, B. B., Jimenez, J. L., Nenes, A., and Weber, R. J.: Evolution of brown carbon in wildfire plumes, Geophys. Res. Lett., 42, 4623-4630, 2015.

GES DISC (Goddard Earth Sciences Data and Information Services Center): OMAERUV product, available at: http://disc.sci. gsfc.nasa.gov/Aura/data-holdings/OMI/, last access: 12 October 2016.

Giglio, L., Randerson, J. T., and van der Werf, G. R.: Analysis of daily, monthly, and annual burned area using the fourthgeneration global fire emissions database (GFED4) J. Geophys. Res.-Biogeo., 118, 317-328, 2013.

Graber, E. R. and Rudich, Y.: Atmospheric HULIS: How humic-like are they? A comprehensive and critical review, Atmos. Chem. Phys., 6, 729-753, doi:10.5194/acp-6-729-2006, 2006.

Hecobian, A., Zhang, X., Zheng, M., Frank, N., Edgerton, E. S., and Weber, R. J.: Water-Soluble Organic Aerosol material and 
the light-absorption characteristics of aqueous extracts measured over the Southeastern United States, Atmos. Chem. Phys., 10, 5965-5977, doi:10.5194/acp-10-5965-2010, 2010.

Herich, H., Hueglin, C., and Buchmann, B.: A 2.5 year's source apportionment study of black carbon from wood burning and fossil fuel combustion at urban and rural sites in Switzerland, Atmos. Meas. Tech., 4, 1409-1420, doi:10.5194/amt-4-1409-2011, 2011.

Holben, B. N., Tanre, D., Smirnov, A., Eck, T. F., Slutsker, I., Abuhassan, N., Newcomb, W. W., Schafer, J. S., Chatenet, B., Lavenu, F., Kaufman, Y. J., Castle, J. V., Setzer, A., Markham, B., Clark, D., Frouin, R., Halthore, R., Karneli, A., O’Neill, N. T., Pietras, C., Pinker, R. T., Voss, K., and Zibordi, G.: An emerging ground-based aerosol climatology: aerosol optical depth from AERONET, J. Geophys. Res., 106, 12067-12097, 2001.

IPCC: Climate Change 2013: The Physical Science Basis: Summary for Policymakers, Cambridge, UK, 2013.

Jethva, H. and Torres, O.: Satellite-based evidence of wavelengthdependent aerosol absorption in biomass burning smoke inferred from Ozone Monitoring Instrument, Atmos. Chem. Phys., 11, 10541-10551, doi:10.5194/acp-11-10541-2011, 2011.

Jethva, H., Torres, O., and Ahn, C.: Global assessment of OMI aerosol single-scattering albedo using ground-based AERONET inversion, J. Geophys. Res.-Atmos., 119, 9020-9040, 2014.

Jo, D. S., Park, R. J., Lee, S., Kim, S.-W., and Zhang, X.: A global simulation of brown carbon: implications for photochemistry and direct radiative effect, Atmos. Chem. Phys., 16, 3413-3432, doi:10.5194/acp-16-3413-2016, 2016.

Kahnert, M. and Devasthale, A.: Black carbon fractal morphology and short-wave radiative impact: a modelling study, Atmos. Chem. Phys., 11, 11745-11759, doi:10.5194/acp-11-117452011, 2011.

Kirchstetter, T. W., T. Novakov, and P. V. Hobbs: Evidence that the spectral dependence of light absorption by aerosols is affected by organic carbon, J. Geophys. Res., 109, D21208, doi:10.1029/2004JD004999, 2004.

Kleinman, L. I., Springston, S. R., Daum, P. H., Lee, Y.-N., Nunnermacker, L. J., Senum, G. I., Wang, J., Weinstein-Lloyd, J., Alexander, M. L., Hubbe, J., Ortega, J., Canagaratna, M. R., and Jayne, J.: The time evolution of aerosol composition over the Mexico City plateau, Atmos. Chem. Phys., 8, 1559-1575, doi:10.5194/acp-8-1559-2008, 2008.

Knox, A., Evans, G. J., Brook, J. R., Yao, X., Jeong, C. H., Godri, K. J., Sabaliauskas, K., and Slowik, J. G.: Mass absorption crosssection of ambient black carbon aerosol in relation to chemical age, Aerosol Sci. Technol., 43, 522-532, 2009.

Koch, D., Schulz, M., Kinne, S., McNaughton, C., Spackman, J. R., Balkanski, Y., Bauer, S., Berntsen, T., Bond, T. C., Boucher, O., Chin, M., Clarke, A., De Luca, N., Dentener, F., Diehl, T., Dubovik, O., Easter, R., Fahey, D. W., Feichter, J., Fillmore, D., Freitag, S., Ghan, S., Ginoux, P., Gong, S., Horowitz, L., Iversen, T., Kirkevåg, A., Klimont, Z., Kondo, Y., Krol, M., Liu, X., Miller, R., Montanaro, V., Moteki, N., Myhre, G., Penner, J. E., Perlwitz, J., Pitari, G., Reddy, S., Sahu, L., Sakamoto, H., Schuster, G., Schwarz, J. P., Seland, Ø., Stier, P., Takegawa, N., Takemura, T., Textor, C., van Aardenne, J. A., and Zhao, Y.: Evaluation of black carbon estimations in global aerosol models, Atmos. Chem. Phys., 9, 9001-9026, doi:10.5194/acp-9-9001-2009, 2009.
Kopke, P., Hess, M., Schult, I., and Shettle, E. P.: Global Aerosol Data Set, Max Planck Institut für Meteorologie, Hamburg, Germany, 1997.

Lack, D. A. and Langridge, J. M.: On the attribution of black and brown carbon light absorption using the Ångström exponent, Atmos. Chem. Phys., 13, 10535-10543, doi:10.5194/acp13-10535-2013, 2013.

Lack, D. A., Langridge, J. M., Bahreini, R., Cappa, C. D., Middlebrook, A. M., and Schwarz, J. P.: Brown carbon and internal mixing in biomass burning particles, P. Natl. Acad. Sci. USA, 109, 14802-14807, 2012.

Laskin, A., Laskin, J., and Nizkorodov, S. A.: Chemistry of atmospheric brown carbon, Chem. Rev., 115, 4335-4382, 2015.

Lee, H. J., Aiona, P. K., Laskin, A., Laskin, J., and Nizkorodov, S. A.: Effect of Solar Radiation on the Optical Properties and Molecular Composition of Laboratory Proxies of Atmospheric Brown Carbon, Environ. Sci. Technol., 48, 10217-10226, 2014.

Lewis, K. A., Arnott, W. P., Moosmüller, H., Chakrabarty, R. K., Carrico, C. M., Kreidenweis, S. M., Day, D. E., Malm, W. C., Laskin, A., Jimenez, J. L., Ulbrich, I. M., Huffman, J. A., Onasch, T. B., Trimborn, A., Liu, L., and Mishchenko, M. I.: Reduction in biomass burning aerosol light absorption upon humidification: roles of inorganically-induced hygroscopicity, particle collapse, and photoacoustic heat and mass transfer, Atmos. Chem. Phys., 9, 8949-8966, doi:10.5194/acp-9-8949-2009, 2009.

Li, Z., Zhao, X., Kahn, R., Mishchenko, M., Remer, L., Lee, K. H., Wang, M., Laszlo, I., Nakajima, T., and Maring, H.: Uncertainties in satellite remote sensing of aerosols and impact on monitoring its long-term trend: a review and perspective, Ann. Geophys., 28, 2755-2770, 2009.

Lin, G., Penner, J. E., Flanner, M. G., Sillman, S., Xu, L., and Zhou, C.: Radiative forcing of organic aerosol in the atmosphere and on snow: effects of SOA and brown carbon, J. Geophys. Res.Atmos., 119, 7453-7476, 2014.

Liousse, C., Cachier, H., and Jennings, S. G.: Optical and thermal measurements of black carbon aerosol content in different environments: Variation of the specific attenuation cross-section, sigma, Atmos. Environ., 27, 1203-1211, 1993.

Liu, J., Scheuer, E., Dibb, J., Diskin, G. S., Ziemba, L. D., Thornhill, K. L., Anderson, B. E., Wisthaler, A., Mikoviny, T., Devi, J. J., Bergin, M., Perring, A. E., Markovic, M. Z., Schwarz, J. P., Campuzano-Jost, P., Day, D. A., Jimenez, J. L., and Weber, R. J.: Brown carbon aerosol in the North American continental troposphere: sources, abundance, and radiative forcing, Atmos. Chem. Phys., 15, 7841-7858, doi:10.5194/acp-15-7841-2015, 2015.

Liu, S., Aiken, A. C., Gorkowski, K., Dubey, M. K., Cappa, C. D., Williams, L. R., Herndon, S., Massoli, P., Fortner, E., Chhabra, P. S., Brooks, W. A., Onasch, T. B., Jayne, J. T., Worsnop, D. R., China, S., Sharma, N., Mazzoleni, C., Xu, L., Ng, N. L., Liu, D., Allan, J. D., Lee, J. D., Fleming, Z. L., Mohr, C., Zotter, P., Szidat, S., and Prevot, A. S. H.: Enhanced light absorption by mixed source black and brown carbon particles in UK winter, Nat. Commun., 6, 8435, doi:10.1038/ncomms9435, 2015.

Martin, S. T., Andreae, M. O., Artaxo, P., Baumgardner, D., Chen, Q., Goldstein, A. H., Guenther, A., Heald, C. L., Mayol-Bracero, O. L., McMurry, P., H., Pauliquevis, T., Pöschl, U., Prather, K. A., Roberts, G. C., Saleska, S. R., Silva Dias, M. A., Spracklen, D. V., Swietlicki, E., and Trebs, I.: Sources and Properties 
of Amazonian Aerosol Particles, Rev. Geophys., 48, RG2002, doi:10.1029/2008RG000280, 2010.

Martin, S. T., Artaxo, P., Machado, L. A. T., Manzi, A. O., Souza, R. A. F., Schumacher, C., Wang, J., Andreae, M. O., Barbosa, H. M. J., Fan, J., Fisch, G., Goldstein, A. H., Guenther, A., Jimenez, J. L., Pöschl, U., Silva Dias, M. A., Smith, J. N., and Wendisch, M.: Introduction: Observations and Modeling of the Green Ocean Amazon (GoAmazon2014/5), Atmos. Chem. Phys., 16, 47854797, doi:10.5194/acp-16-4785-2016, 2016.

Martinsson, J., Eriksson, A. C., Elbæk Nielsen, I., Berg Malmborg, V., Ahlberg, E., Andersen, C., Lindgren, R., Nyström, R., Nordin, E. Z., Brune, W. H., Svenningsson, B., Swietlicki, E., Boman, C., and Pagels, J. H.: Impacts of Combustion Conditions and Photochemical Processing on the Light Absorption of Biomass Combustion Aerosol, Environ. Sci. Technol., 49, 14663-14671, 2015.

Moffet, R. C. and Prather, K. A.: In-situ measurements of the mixing state and optical properties of soot with implications for radiative forcing estimates, P. Natl. Acad. Sci. USA, 106, 1187211877, 2009.

Myhre, G., Samset, B. H., Schulz, M., Balkanski, Y., Bauer, S., Berntsen, T. K., Bian, H., Bellouin, N., Chin, M., Diehl, T., Easter, R. C., Feichter, J., Ghan, S. J., Hauglustaine, D., Iversen, T., Kinne, S., Kirkevåg, A., Lamarque, J.-F., Lin, G., Liu, X., Lund, M. T., Luo, G., Ma, X., van Noije, T., Penner, J. E., Rasch, P. J., Ruiz, A., Seland, Ø., Skeie, R. B., Stier, P., Takemura, T., Tsigaridis, K., Wang, P., Wang, Z., Xu, L., Yu, H., Yu, F., Yoon, J.-H., Zhang, K., Zhang, H., and Zhou, C.: Radiative forcing of the direct aerosol effect from AeroCom Phase II simulations, Atmos. Chem. Phys., 13, 1853-1877, doi:10.5194/acp-13-18532013, 2013.

NASA: AERONET data, available at: http://aeronet.gsfc.nasa.gov/, last access: 12 October 2016.

Olson, M. R., Victoria Garcia, M., Robinson, M. A., Van Rooy, P., Dietenberger, M. A., Bergin, M., and Schauer, J. J.: Investigation of black and brown carbon multiplewavelength-dependent light absorption from biomass and fossil fuel combustion source emissions, J. Geophys. Res.-Atmos., 120, 6682-6697, 2015.

Ramanathan, V., Li, F., Ramana, M. V., Praveen, P. S., Kim, D., Corrigan, C. E., Nguyen, H., Stone, E. A., Schauer, J. J., Carmichael, G. R., Adhikary, B., and Yoon, S. C.: Atmospheric brown clouds: Hemspherical and regional variations in long-range transport, absorption, and radiative forcing, J. Geophys. Res., 112, D22S21, doi:10.1029/2006JD008124, 2007.

Rizzo, L. V., Correia, A. L., Artaxo, P., Procópio, A. S., and Andreae, M. O.: Spectral dependence of aerosol light absorption over the Amazon Basin, Atmos. Chem. Phys., 11, 8899-8912, doi:10.5194/acp-11-8899-2011, 2011.

Russell, P. B., Bergstrom, R. W., Shinozuka, Y., Clarke, A. D., DeCarlo, P. F., Jimenez, J. L., Livingston, J. M., Redemann, J., Dubovik, O., and Strawa, A.: Absorption Angstrom Exponent in AERONET and related data as an indicator of aerosol composition, Atmos. Chem. Phys., 10, 1155-1169, doi:10.5194/acp-101155-2010, 2010.

Saleh, R., Robinson, E. S., Tkacik, D. S., Ahern, A. T., Liu, S., Aiken, A. C., Sullivan, R., C., Presto, A. A., Dubey, M. K., Yokelson, R. J., Donahue, N. M., and Robinson, A. L.: Brownness of organics in aerosols from biomass burning linked to their black carbon content, Nat. Geosci., 7, 647-650, 2014.
Saleh, R., Marks, M., Heo, J., Adams, P. J., Donahue, N. M., and Robinson, A. L.: Contribution of brown carbon and lensing to the direct radiative effect of carbonaceous aerosols from biomass and biofuel burning emissions, J. Geophys. Res.-Atmos., 120, 10285-10296, 2015.

Sander, S. P., Abbatt, J., Barker, J. R., Burkholder, J. B., Friedl, R. R., Golden, D. M., Huie, R. E., Kolb, C. E., Kurylo, M. J., Moortgat, G. K., Orkin, V. L., and Wine, P. H.: Chemical kinetics and photochemical data for use in atmospheric studies, Evaluation number 17, Vol. JPL Publication 10-6, Jet Propulsion Laboratory, Pasadena, 2011.

Sandradewi, J., Prevot, A. S. H., Szidat, S., Perron, N., Alfarra, M. R., Lanz, V. A., Weingartner, E., and Baltensperger, U.: Using Aerosol Light Absorption Measurements for the Quantitative Determination of Wood Burning and Traffic Emission Contributions to Particulate Matter, Envir. Sci. Tech., 42, 3316-3323, 2008.

Sayer, A. M., Hsu, N. C., Eck, T. F., Smirnov, A., and Holben, B. N.: AERONET-based models of smoke-dominated aerosol near source regions and transported over oceans, and implications for satellite retrievals of aerosol optical depth, Atmos. Chem. Phys., 14, 11493-11523, doi:10.5194/acp-14-11493-2014, 2014.

Schmid, O., Artaxo, P., Arnott, W. P., Chand, D., Gatti, L. V., Frank, G. P., Hoffer, A., Schnaiter, M., and Andreae, M. O.: Spectral light absorption by ambient aerosols influenced by biomass burning in the Amazon Basin. I: Comparison and field calibration of absorption measurement techniques, Atmos. Chem. Phys., 6, 3443-3462, doi:10.5194/acp-6-3443-2006, 2006.

Schwarz, J. P., Gao, R. S., Spackman, J. R., Watts, L. A., Thomson, D. S., Fahey, D. W., Ryerson, T. B., Peischl, J., Holloway, J. S., Trainer, M., Frost, G. J., Baynard, T., Lack, D. A., de Gouw, J. A., Warneke, C., and Del Negro, L. A.: Measurement of the mixing state, mass, and optical size of individual black carbon particles in urban and biomass burning emissions, Geophys. Res. Lett., 35, L13810, doi:10.1029/2008GL033968, 2008.

Shamjad, P. M., Tripathi, S. N., Aggarwal, S. G., Mishra, S. K., Joshi, M., Khan, A., Sapra, B. K., and Ram, K.: Comparison of experimental and modeled absorption enhancement by black carbon (BC) cored poly disperse aerosols under hygroscopic conditions, Environ. Sci. Technol., 46, 8082-8089, 2012.

Shiraiwa, M., Kondo, Y., Iwamoto, T., and Kita, K.: Amplification of Light Absorption of Black Carbon by Organic Coating, Aerosol Sci. Technol., 44, 46-54, 2010.

Stone, D., Whalley, L. K., and Hearld, D. E.: Tropospheric $\mathrm{OH}$ and $\mathrm{HO}_{2}$ radicals: field measurements and model comparisons, Chem. Soc. Rev., 41, 6348-6404, 2012.

Streets, D. G., Bond, T. C., Lee, T., and Jang, C.: On the future of carbonaceous aerosol emissions, J. Geophys. Res., 109, D24212, doi:10.1029/2004JD004902, 2004.

Tesche, M., Muller, D., Gross, S., Ansmann, A., Althausen, D., Freudenthaler, V., Weinzierl, B., Veira, A., and Petzold, A.: Optical and microphysical properties of smoke over Cape Verde inferred from multiwavelength lidar measurements, Tellus B, 63, 403-813, doi:10.1111/j.1600-0889.2011.00549.x, 2011.

Torres, O., Tanskanen, A., Veihelmann, B., Ahn, C., Braak, R., Bhartia, P. K., Veefkind, P., and Levelt, P.: Aerosols and surface UV products from Ozone Monitoring Instrument observations: An overview, J. Geophys. Res., 112, D24S47, doi:10.1029/2007JD008809, 2007. 
Turpin, B. J., Lim, H. J.: Species contributions to PM2.5 mass concentrations: revisiting common assumptions for estimating organic mass, Aerosol Sci. Technol., 35, 602-610, 2001.

Wang, X., Heald, C. L., Ridley, D. A., Schwarz, J. P., Spackman, J. R., Perring, A. E., Coe, H., Liu, D., and Clarke, A. D.: Exploiting simultaneous observational constraints on mass and absorption to estimate the global direct radiative forcing of black carbon and brown carbon, Atmos. Chem. Phys., 14, 10989-11010, doi:10.5194/acp-14-10989-2014, 2014.

Washenfelder, R. A., Attwood, A. R., Brock, C. A., Guo, H., Xu, L., Weber, R. J., Ng, N. L., Allen, H. M., Ayres, B. R., Baumann, K., Cohen, E. C., Draper, D. C., Duffey, K. C., Edgerton, E., Fry, J. L., Hu, W. W., Jimenez, J. L., Palm, B. B., Romer, P., Stone, E. A., Wooldridge, P. J., and Brown, S. S.: Biomass burning dominates brown carbon absorption in the rural southeastern United States, Geophys. Res. Lett., 42, 653-664, 2015.

Weingartner, E., Saathof, H., Schnaiter, M., Streit, N., Bitnar, B., and Baltensperger, U.: Absorption of light by soot particles: Determination of the absorption coefficient by means of Aethalometers, J. Aerosol Sci., 34, 1445-1463, 2003.

Yang, M., Howell, S. G., Zhuang, J., and Huebert, B. J.: Attribution of aerosol light absorption to black carbon, brown carbon, and dust in China - interpretations of atmospheric measurements during EAST-AIRE, Atmos. Chem. Phys., 9, 2035-2050, doi:10.5194/acp-9-2035-2009, 2009.

Zaveri, R. A., Shaw, W. J., Cziczo, D. J., Schmid, B., Ferrare, R. A., Alexander, M. L., Alexandrov, M., Alvarez, R. J., Arnott, W. P., Atkinson, D. B., Baidar, S., Banta, R. M., Barnard, J. C., Beranek, J., Berg, L. K., Brechtel, F., Brewer, W. A., Cahill, J. F., Cairns, B., Cappa, C. D., Chand, D., China, S., Comstock, J. M.,Dubey, M. K., Easter, R. C., Erickson, M. H., Fast, J. D., Floerchinger, C., Flowers, B. A., Fortner, E., Gaffney, J. S., Gilles, M. K., Gorkowski, K., Gustafson, W. I., Gyawali, M., Hair, J., Hardesty, R. M., Harworth, J. W., Herndon, S., Hiranuma, N., Hostetler, C., Hubbe, J. M., Jayne, J. T., Jeong, H., Jobson, B. T., Kassianov, E. I., Kleinman, L. I., Kluzek, C., Knighton, B., Kolesar, K. R., Kuang, C., Kubátová, A., Langford, A. O., Laskin, A., Laulainen, N., Marchbanks, R. D., Mazzoleni, C., Mei, F., Moffet, R. C., Nelson, D., Obland, M. D., Oetjen, H., Onasch, T. B., Ortega, I., Ottaviani, M., Pekour, M., Prather, K. A., Radney, J. G., Rogers, R. R., Sandberg, S. P., Sedlacek, A., Senff, C. J., Senum, G., Setyan, A., Shilling, J. E., Shrivastava, M., Song, C., Springston, S. R., Subramanian, R., Suski, K., Tomlinson, J., Volkamer, R., Wallace, H. W., Wang, J., Weickmann, A. M., Worsnop, D. R., Yu, X.-Y., Zelenyuk, A., and Zhang, Q.: Overview of the 2010 Carbonaceous Aerosols and Radiative Effects Study (CARES), Atmos. Chem. Phys., 12, 7647-7687, doi:10.5194/acp-12-7647-2012, 2012.
Zhang, X. L., Lin, Y. H., Surratt, J. D., and Weber, R. J.: Sources, Composition and Absorption Ångström Exponent of Light absorbing Organic Components in Aerosol Extracts from the Los Angeles Basin, Environ. Sci. Technol., 47, 3685-3693, 2013.

Zhao, R., Lee, A. K. Y., Huang, L., Li, X., Yang, F., and Abbatt, J. P. D.: Photochemical processing of aqueous atmospheric brown carbon, Atmos. Chem. Phys., 15, 6087-6100, doi:10.5194/acp15-6087-2015, 2015.

Zhong, M. and Jang, M.: Light absorption coefficient measurement of SOA using a UV - Visible spectrometer connected with an integrating sphere, Atmos. Environ., 45, 4263-4271, 2011. 